\title{
Justice Story, Slavery, and the Natural Law Foundations of American Constitutionalism
}

\author{
Christopher L.M. Eisgruber $\dagger$
}

Justice Joseph Story proclaimed his opinion for the Supreme Court in Prigg $v$. Pennsylvania to be a "triumph of freedom." The Court's decision in that 1842 case held unconstitutional a Pennsylvania law opposed by slaveholders because the statute interposed procedural barriers to the recapture of escaped slaves. Few commentators have shared Story's assessment of his opinion, and in recent years several prominent scholars have criticized Story's treatment of the slavery question on both ethical and jurisprudential grounds.

This comment proposes to rehabilitate Justice Story's opinion in Prigg. In particular, the comment aims to show that proper attention to the natural law foundations of Story's thought provides a coherent and insightful account of the slavery problem and the American response to that problem. In so doing, the comment provides reasons to believe both that modern critics have misunderstood Story's thought and that Story's ideas may deserve the attention of the ongoing debate over the meaning and significance of natural law. ${ }^{2}$ Section I describes the facts and background of Prigg,

† A.B. 1983, Princeton University; M.Litt. 1985, Oxford University; J.D. Candidate 1988, The University of Chicago.

141 U.S. 539 (1842). The quotation appears in William W. Story, ed., 2 Life and Letters of Joseph Story 392 (1851) ("Life and Letters").

2 The ongoing debate includes such recent works as Thomas C. Grey, Do We Have an Unwritten Constitution?, 27 Stan.L.Rev. 703 (1975); John Finnis, Natural Law and Natural Rights (1980); Rogers M. Smith, Liberalism and American Constitutional Law (1985); Michael S. Moore, A Natural Law Theory of Interpretation, 58 So.Cal.L.Rev. 277 (1985); Suzanna Sherry, The Founders' Unwritten Constitution, 54 U.Chi.L.Rev. 1124 (1987); and Lloyd Weinreb, Natural Law and Justice (1987), as well as the critical responses to these works.

While even those friendly to natural law often disagree about what natural law is, critics of this tradition have further clouded the concept by arguing against caricatures of the idea. See Finnis, Natural Law and Natural Rights at 23-55. This comment does not attempt to confine Story's view of natural law within any presently dominant view, caricature or otherwise. Indeed, as will be discussed below, careful interpretation of Story's thought reveals that Story's view of natural law contradicts many present day opinions about the subject. 
and summarizes Story's disposition of the case. Section II presents the arguments of Ronald Dworkin, R. Kent Newmyer, and Robert Cover, three leading modern critics of Story. Section III begins a defense of Story by setting out Story's science of natural law. Finally, Section IV applies Story's thought on natural law to answer the arguments of his modern critics. ${ }^{3}$

\section{The Case of Prigg v. Pennsylvania}

\section{A. Facts of the Case}

Article IV, section 2, paragraph 3 of the Constitution provides ${ }^{4}$ that "No Person held to Service or Labour in one State, under the Laws thereof, escaping into another, shall, in Consequence of any Law or Regulation therein, be discharged from such Service or Labour, but shall be delivered up on Claim of the Party to whom such Service or Labour may be due." Although the cleverly worded clause neither expressly mentions nor implicitly authorizes slavery, ${ }^{\sigma}$ the clear intent of the clause was to give the Southern states some guarantee that slaveowners could recapture slaves who had escaped to the North. But as Thomas Morris points out, the clause is less clear about the means by which such recapture should occur, and about who, if anyone, should legislatively implement the clause. Is the recapture of escaped slaves a matter for Congress, the states, or both? ${ }^{\circ}$ The question was hotly disputed prior to the Civil War. The Southern states were interested primarily in effective and efficient processes of recapture. This interest conflicted with that of the Northern states, where citizens sought to protect free blacks and (at least in some circles) emancipate enslaved blacks. Prigg presented to the Supreme Court the question of who had legislative authority to sort these interests and enforce the clause.

Sometime during 1832, Margaret Morgan, a black woman enslaved for life to Margaret Ashmore, escaped from Ashmore's

${ }^{3}$ My treatment of this topic owes much to Herbert J. Storing, Slavery and the Moral Foundations of the American Republic, in Robert H. Horwitz, ed., The Moral Foundations of the American Republic 214 (1977) ("Slavery and the Republic"). Storing's essay mentions, without discussing in detail, Story's opinion in Prigg. Id. at 218.

- The provision is, of course, now a nullity because of the enactment of the thirteenth amendment.

- It would be consistent with the words of the fugitive slave clause to argue that those persons held to service or labour in one state may not be freed in another, but that no persons may legitimately be enslaved in any state. See Storing, Slavery and the Republic at 221, 223-25 (cited in note 3).

B Thomas D. Morris, Free Men All 18 (1974). 
Maryland residence and fled to Pennsylvania. For the next five years, Morgan lived in Pennsylvania with her husband and her children. But then in February 1837, Edward Prigg, acting as Ashmore's legal agent, went to Pennsylvania to capture Morgan and return her to slavery. ${ }^{7}$

In order to effect Morgan's return, Prigg had to abide by a March 1826 act of the Pennsylvania legislature entitled "An act to give effect to the provisions of the Constitution of the United States relative to fugitives from labour, for the protection of free people of colour, and to prevent kidnapping." The statute established a state process for the rendition of fugitive slaves that required slavechasers like Prigg to appeal to a Pennsylvania "judge, justice of the peace or alderman" for a warrant directing a sheriff or similar officer to arrest the alleged fugitive. After arrest, the alleged fugitive had to be brought before the same magistrate who had issued the warrant; this magistrate would preside over proceedings designed to determine the verity of the slavecatcher's claims. The act also declared that no Pennsylvania alderman or justice of the peace had jurisdiction over, or would take cognizance of, claims arising under the Fugitive Slave Act passed by Congress in $1793 .^{\circ}$

Prigg appeared before Thomas Henderson, justice of the peace for York County, Pennsylvania, in February of 1837 and obtained the necessary warrant. Yet when officers brought Morgan before Henderson, the justice of the peace refused, for reasons not explained in the record, to take any further cognizance of the matter. Prigg nonetheless took Morgan and her children back to Maryland, thereby violating Pennsylvania law. Prigg was arraigned and charged in York County on April 1, 1837; he pled not guilty and was tried May 22, 1839. The jury found by special verdict the facts summarized in this and the preceding paragraph, and the court pronounced Prigg guilty of kidnapping. Prigg prosecuted successive writs of error, first to the Supreme Court of Pennsylvania and then, after the Pennsylvania court affirmed conviction, to the United States Supreme Court. ${ }^{9}$

\section{B. The Fugitive Slave Act and the Personal Liberty Laws}

In order to appreciate the issues raised by Prigg, it is essential

7 Prigg, 41 U.S. at 556-57.

- Id. at 550-56.

- Id. at 543, 556-57. 
to understand the national importance of the fugitive slave problem in 1842, when Prigg was decided. Throughout the nation's history, the efforts of Southern slaveholders to recapture escaped slaves generated two related political problems. Initially, the state and federal governments had to decide how to secure the rights apparently guaranteed to slaveowners by the fugitive slave clause: what processes, if any, were appropriate to regulate the recapture of slaves? At the same time, the governments had to find a way to protect the rights of free blacks whom slaveowners might deliberately or mistakenly kidnap. Of course, the rights of fugitive slaves themselves also came into play, as seen initially in the attempts of some of the Northern states to protect fugitives from abuse by violent slavecatchers and, eventually, through their efforts to emancipate the escapees. Nonetheless, early in the nation's history the crafting of fugitive slave laws attended primarily to the property rights of slaveowners and the liberty of free blacks. ${ }^{10}$

While they all had to balance the rights of slaves and their owners, the Northern and Southern states weighed them in different ways. In the South, "the resolution of this tension was weighted in favor of slaveholders by means of a presumption that would serve as a guide to a court in any hearing involving the status of a black. The presumption was that all blacks were slaves." 11 The presumption in the Northern states, by contrast, was radically different. The Northern states enacted procedural restrictions on the recapture of slaves, restrictions embodying a "clear-cut and allimportant presumption of freedom" in an attempt to "affirm through law the presumption that all men are free until proven otherwise by orderly procedures." 12

The practical consequences (or, at the very least, the perceived consequences) of the different presumptions of the Northern and Southern states provoked considerable political agitation. Controversy erupted as early as the second decade of the nineteenth century, when Congress debated various proposed changes to the Fugitive Slave Act of 1793. With the end of the War of 1812, the country's political intellect diverted its attention from foreign affairs to domestic self-criticism. In the North, this self-criticism led to the growth of a "wide-ranging humanism" which, together with Jesse Torrey's 1817 tract detailing the slave trade's capture of free

${ }^{10}$ Morris, Free Men All at 29 (cited in note 6).

11 Id. at 2.

12 Id. at 5-6, ix. For a discussion of the particular procedural restrictions employed by the Northern states, see id. at 6-12. 
American blacks, heightened Northern concern over kidnapping. The Southern states, meanwhile, complained that Northern laws and courts inadequately respected the property rights of slaveowners:

According to proslavery people northern courts often favored claims to freedom, and in some areas antislavery people continuously flouted the law by assisting runaways, and without penalty. . . . As for the legal processes of the free states, Judge Spencer Roane of Virginia forcefully stated the proslavery view in December, 1821, in Lewis v. Fullerton: the right to reclaim fugitive slaves would be "nearly a nullity" if the courts of the free states could confer liberty by the simple expedient of a habeas corpus. ${ }^{13}$

Nevertheless, as Morris points out, "neither side had sufficient political power to alter the existing arrangement,"14 and so the debates over amending the Fugitive Slave Act ended inconclusively in 1822. The Northern states, unhappy with the summary procedures specified by the 1793 Act and having lost hope for a federal remedy to the kidnapping problem, began to pass state legislation. Pennsylvania's experience during this time reveals the symptoms of these concerns. Pennsylvania passed an act in 1820 that imposed severe penalties upon those who by force or fraud kidnapped free blacks, as well as limited the reach of the federal Fugitive Slave Act by denying certain lower state officials jurisdiction to enforce the federal Act. The 1820 Act required those few state officials who did retain jurisdiction to maintain a record, including a description of the alleged slave, of all proceedings pursuant to the federal Act. By proscribing the participation of state officials in federal fugitive slave proceedings, Pennsylvania made it substantially more difficult for slavechasers to recapture fugitives. In fact, there were so few qualified Pennsylvania and federal officials available to hear the claims of Southern slaveholders after the Act of 1820 that the state of Maryland actively lobbied to change the law. Pennsylvania responded to these concerns in 1826 with the act that gave rise to Prigg. ${ }^{15}$

The Act of 1826 was a compromise, one that established a separate, state procedure for the rendition of fugitive slaves and empowered lower state officials to enforce it. Although the new proce-

\footnotetext{
13 Id. at 29-35.

14 Id. at 41.

${ }^{15}$ Id. at $45-46$.
} 
dure itself was less favorable to Southern slaveholders than was the federal procedure, it was nonetheless more useful to the slavechasers because state officials were more numerous than were federal officials. In exchange for giving Southern slaveholders this new procedure, Northern antislavery forces obtained the elimination of the slavechasers' historical right to simply retake, when possible without violence, those blacks whose status as fugitives was undisputed. After 1826, any taking of any alleged fugitive in Pennsylvania could occur legally only if done with judicial approval. ${ }^{16}$

The precise impact and intent of the 1826 Act are unclear. One historian has argued that the Act was intended to and did make it virtually impossible for Southerners to recover fugitive slaves in Pennsylvania. ${ }^{17}$ An earlier historian points out, however, that the Act's concessions to slaveholders were significant. ${ }^{18}$ Perhaps the most persuasive evidence of the Act's mixed pro- and antislavery character is that both the Pennsylvania Abolition Society and the Maryland commissioners who lobbied the Pennsylvania legislature were relatively satisfied with the Act. ${ }^{19}$

In any event, the peace earned by the compromise of 1826 , whatever its character, began to erode within the next decade. Intensified by the debate over whether new states and territories should be slave or free, the slavery controversy became increasingly heated and its parties increasingly polarized. Proponents of immediate abolition emerged as a visible and sometimes potent political force in the North. Because Northerners were growing less conciliatory or because the rhetoric of abolition and the politics of antislavery generated an understandable distrust and suspicion, the South became dissatisfied with the fugitive slave laws of the Northern states. By 1840, tensions over state treatment of fugitive slaves were sufficiently great that Maryland sought, and Pennsylvania provided, pro forma proceedings in the Prigg case so as to facilitate a quick Supreme Court decision spelling out the limits of state power to legislate on the matter of fugitive slaves. The matter, of course, did not end there. By 1850, the Southern states, taking advantage of the fear of some Northern moderates that the Union was near dissolution, were able to obtain a new and harshly

16 Id. at $46-53$.

17 See William R. Leslie, The Pennsylvania Fugitive Slave Act of 1826, 18 J.So.Hist. 429,445 (1952).

18 John Bach McMaster, 5 A History of the People of the United States 218 (1900).

19 Morris, Free Men All 52-53 (cited in note 6). 
stringent federal slave law to address the inadequacies they perceived in the statutes of the Northern states. And by 1860, when South Carolina did secede, that state cited the Northern state laws prohibiting kidnapping and regulating the recapture of fugitive slaves as one of the factors contributing to its decision to depart from the Union. ${ }^{20}$

\section{Justice Story's Opinion in Prigg}

Prigg $v$. Pennsylvania forced the Supreme Court to address issues that agitated an intense national moral and political conflict. The difficulty of the questions raised in Prigg and the fugitive slave controversy more generally bore keenly upon the conscience of Justice Story who, as a profound opponent of slavery and a profound student of the Constitution, must have listened with deep discomfort to those Northern abolitionists who characterized the Constitution as a damnable proslavery compact. ${ }^{21}$ Story's opinion for the Court in Prigg ${ }^{22}$ was both blunt and subtle, addressing

${ }^{20}$ Id. at $94-95,146-48,1$.

31 There is little doubt, among either Story's critics or his disciples, that the Justice personally condemned slavery. See, e.g., Joseph Story, Piracy and the Slave Trade, in William W. Story, ed., The Miscellaneous Writings of Joseph Story 136 (1852) ("The existence of slavery, under any shape, is so repugnant to the natural rights of man and the dictates of justice, that it seems difficult to find for it any adequate justification."). See also R. Kent Newmyer, Supreme Court Justice Joseph Story 345, 351 (1985) ("Justice Joseph Story"); Robert M. Cover, Justice Accused 239-240 (1975); Storing, Slavery and the Republic at 218 (cited in note 3); Story, 2 Life and Letters at 391 (cited in note 1). Additional judicial evidence of Story's opposition to slavery is his lengthy condemnation of the slave trade in United States v. La Jeune Eugenie, 26 F.Cases 832, 845-46 (C.C.D.Mass. 1822), a piracy case decided by Story while riding circuit.

Story's preface to his Commentaries on the Constitution provides evidence, if any is necessary, of both Story's assiduous study of the Constitution and his devotion to the document. See Joseph Story, 1 Commentaries on the Constitution of the United States v-vii (1833) ("Commentaries on the Constitution").

For the arguments of those who thought the Constitution a proslavery compact, see the discussion of the Garrisonians in Cover, Justice Accused at 150-54. See also Newmyer, Justice Joseph Story at 346. For an important modern echo of this view, see Thurgood Marshall, Reflections on the Bicentennial of the United States Constitution, 101 Harv.L.Rev. 1 (1987). The fugitive slave clause in Article IV is the provision that most prominently and openly facilitated the continuation of slavery. The Constitution also discreetly acknowledged the existence of slavery in two other provisions. See U.S. Const. art. I, § 2, cl. 3 (declaring that, for purposes of legislative apportionment, population would be determined by adding the whole number of free persons and indentured servants, excluding Indians not taxed, and by including three-fifths of "all other persons"); and U.S. Const. art. I, § 9, cl. 1 ("The migration or importation of such persons as any of the states now existing shall think proper to admit, shall not be prohibited by the Congress prior to the year one thousand eight hundred and eight. . ...").

2241 U.S. at 608. Though the official reporter announces Story's opinion as that of the Court, six of Story's colleagues (Taney, Thompson, Baldwin, Wayne, Daniel, and McLean) 
the political and Constitutional problems in an open and determinative fashion while taking note of fine distinctions that altered, if not the disposition of the case, then certainly its political and constitutional significance.

Story begins his exegesis of the fugitive slave clause by stating plainly what the Constitution itself implies but does not articulate: "the object of this clause was to secure to the citizens of the slaveholding states the complete right and title of ownership in their slaves, as property, in every state in the Union into which they might escape. . . " However distasteful or unappealing this purpose might be (and certainly it was distasteful to Story), it was a purpose nonetheless clear and essential, for "without the adoption of [the fugitive slave clause] the Union could not have been formed." 23

Story leaves no doubt, however, that the clause is essential only as a consequence of practical necessity, and not as an enforcement or declaration of what is naturally right or what naturally belongs to the South. "The state of slavery," says Story, "is deemed to be a mere municipal regulation, founded upon and limited to the range of the territorial laws." ${ }^{24}$ We may reason from Story's Commentaries on the Constitution that municipal regulations differ from other laws in that they provide for "private or local convenience" rather than the "public good." state of slavery is a mere municipal regulation, no free state is bound to recognize the claims of slaveholders, and, in the absence of the fugitive slave clause, "every non-slave-holding state in the Union would have been at liberty to have declared free all runaway slaves coming within its limits. . . ." The fugitive slave clause was therefore drafted to protect the interests of the Southern states,

filed concurring opinions, and, as several commentators have pointed out, it is not clear how much of Story's opinion was shared by a majority of the Court. See, e.g., Newmyer, Justice Joseph Story at 374-75, and David P. Currie, The Constitution in the Supreme Court: The First Hundred Years 1789-1889 242-45 (1985) ("First Hundred Years").

${ }^{23}$ Prigg, 41 U.S. at 611.

24 Id. Story's assertion that slavery had the status of a mere municipal regulation follows Lord Mansfield's reasoning in Somerset's Case, 1 Lofft's Rep. 1, 20 Howell's State Trials 1, 98 Eng.Rep. 499 (1772). Somerset's Case, which dealt with the extraterritorial effect of slave laws, played a crucial role in antislavery jurisprudence because it recognized that slavery was unacceptable in the absence of contrary positive law. See, e.g., Cover, Justice Accused at 16-17 (cited in note 21). Story reported and endorsed Mansfield's decision in Somerset's Case in Joseph Story, Commentaries on the Conflict of Laws 92 (1834).

${ }^{25}$ Story, 1 Commentaries on the Constitution at $\$ 421$ (cited in note 21 ). It is obviously an interesting question to ask what relationship the public good has to private and local convenience. That general question is, however, best postponed until Section III, which examines the foundations of Story's jurisprudential thought. 
and its unanimous adoption is proof "of its intrinsic and practical necessity." Since the clause is a product of necessity, it must be construed to effectuate its purpose. ${ }^{26}$ If the clause is as necessary to preservation of the Union as it was to formation of the Union, then the consequence of failing to construe the clause effectively would be dissolution of the Union. ${ }^{27}$

To effect the clause's purposes in his construction, Story begins by considering the first half of the fugitive slave clause. That part of the clause states that "[t]he slave is not to be discharged from service or labour, in consequence of any state law or regulation." Story argues that a slave is discharged "in consequence" of a state law or regulation if "the natural or necessary operation" of that law or regulation in any respect "interrupts, limits, delays, or postpones the right of the owner to immediate possession of the slave, and the immediate command of his service."28 The clause therefore prohibits not only those state statutes that, by their terms, free escaped slaves, but also those statutes which interpose procedural barriers to their recapture. ${ }^{2 \theta}$ The object of the clause, Story tells us, is to secure to the slaveholder a "positive, unqualified right" to repossess an escaped slave. ${ }^{30}$

The right of the slaveholder secured by the first section of the fugitive slave clause is self-executing insofar as it grants him "entire authority, in every state in the Union, to seize and recapture his slave, whenever he can do it without any breach of the peace,

28 Prigg, 41 U.S. at 612.

${ }^{27}$ This consequence may appear implausibly extreme to the modern reader, but it is essential to remember that Story wrote at a time when the doctrine of state nullification of constitutional rules was vigorously espoused, and when the Civil War was only twenty years away.

${ }^{28}$ Prigg, 41 U.S. at 612-13.

20 The text of the clause provides specific evidence that its framers were particularly concerned that such procedural barriers might reflect not merely the necessary incidents of the legal process but rather local antislavery policies: the clause prohibits not simply the discharge of escaped slaves by state law or regulation but the discharge of escaped slaves in consequence of local statute. This difference between "by" and "in consequence of" was important and obvious enough to attract the attention of the attorneys who argued Prigg. Hambly, arguing for Pennsylvania, at a key point in his argument elides "in consequence of" and replaces that phrase with "by." Id. at 574. Meredith, arguing for Maryland, read the first half of the clause to prohibit states from enacting any law "by which fugitives from labor may be discharged from service," thus preserving the implication that laws which effect discharge through procedural delay are no less void than laws which simply declare escaped slaves to be free. Id. at 561. Meredith later adverts to the fear that Northern states might in fact frustrate the recapture of escaped slaves by erecting procedural obstacles. Id. at 565 .

so Id. at 612-13. 
or any illegal violence."31 This self-executing aspect of the clause fails, however, to effectuate the clause's purposes, since the slaveholder may find it impossible to recapture an escaped slave without violence or breach of the peace, particularly in the face of local resistance or non-cooperation. According to Story, the framers of the Constitution addressed this need for an effective legal remedy in the second part of the clause, which provides that the person held to labor or service "shall be delivered up on Claim of the Party to whom such Service or Labour may be due."32 In order to make this legal remedy practical, a judicial officer must have the power and the obligation to adjudicate slavechasers' claims. Moreover, legislation is required to decide what sort of claim the clause prescribes, to whom such a claim must be made, and how and when delivery will take place. ${ }^{33}$

Because both judicial and legislative action are necessary to effectuate a constitutional end, the Constitution must be construed, if possible, to provide somewhere for the power to undertake those actions. The duty to provide legislative and judicial proceedings falls upon the federal government, rather than upon the states, for the "clause is found in the national constitution, and not in that of any state," and, since the institution of slavery is a mere municipal regulation, the duty to legislate to provide for the recapture of fugitive slaves is purely the product of the positive provisions of the national Constitution. Indeed, Story says, the "states cannot. . .be compelled to enforce" the provisions of the Fugitive Slave Act. ${ }^{34}$ Story reasons further that the "Claim" of the slaveowning "Party" envisioned by the clause must be a claim against someone, and so it must be a claim that is adversarial in character. Because the states cannot be compelled to carry into effect the second part of the Fugitive Slave Act, the adversarial claim is necessarily a "Case. . .arising under [the] Constitution" within the meaning of Article III. ${ }^{35}$ The claim therefore falls within the federal judicial power. Therefore, Story concludes in finishing this intricate argument, Congress has the power to enact whatever legislation is necessary to permit federal judicial redress of claims by slaveowners under the fugitive slave clause, since Congress has the power to "make all Laws which shall be necessary and proper for

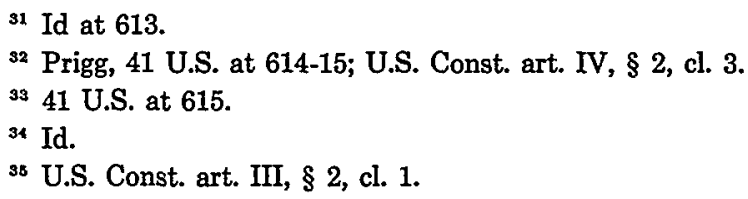


carrying into Execution . . . all . . Powers vested by this Constitution in the Government of the United States, or in any Department or Officer thereof." 36

After completing this rather complex argument confirming Congressional authority to legislate in furtherance of the ends of the fugitive slave clause, Story observes that Congress has taken "this very view of the power and duty of the national government." $\mathrm{Hz}$ then summarizes the relevant provisions of the Fugitive Slave Act of $1793 .^{38}$ That Act, he suggests, "may be truly said to cover the whole ground of the Constitution, both as to fugitives from justice, and fugitive slaves" because "it points out fully all the modes of attaining those objects, which Congress, in their discretion, have as yet deemed expedient or proper to meet the exigencies of the Constitution." Story contends that Congress, by legislating to provide remedies for slavechasers, must have precluded state legislation on the subject, since

if congress have a constitutional power to regulate a particular subject, and they do actually regulate it in a given manner, and in a certain form, it cannot be, that the state legislatures have a right to interfere, and . . . by way of complement to the legislation of Congress, to prescribe additional regulations ... for the same purpose. ${ }^{39}$

Rather than develop the argument that Congressional action on the fugitive slave question precludes state legislation, Story takes up, at some length, the question whether the constitutional necessity of Congressional legislative action under the fugitive slave clause suffices to establish Congress' power to legislate. Story first surveys the various areas in which Congress has derived and the Court has approved legislative powers by implication from the Constitution's description of federal functions and duties. He then argues that, just as with the implied legislative powers in those other examples, the courts have long conceded the Fugitive Slave Act to be a legitimate exercise of Congressional power to enforce the fugitive slave clause. At the close of this discussion, Story pronounces that the Fugitive Slave Act is "clearly constitutional in all its leading provisions." He leaves unclear, however, the question

s6 Prigg, 41 U.S. at 616; U.S. Const. art. I, § 8, cl. 18.

37 Prigg, 41 U.S. at 616.

38 Fugitive Slave Act, 1 Stat. 302 (1798).

30 Prigg, 41 U.S. at 616-18. It is not at all clear how heavily Story intends to rely upon this argument; see below at note 78 . 
whether state magistrates may be compelled to enforce the Act, saying that the Court entertains no doubt that "state magistrates, may, if they choose, exercise that authority, unless prohibited by state legislation." 40

According to Story, the "remaining question is, whether the power of legislation upon this subject is exclusive in the national government, or concurrent in the states, until it is exercised by Congress." 11 it is not clear in what sense this question "remains," since in fact Congress had legislated upon the fugitive slave problem, and so apparently rendered Story's question moot. There are at least two reasons, however, why Story might have thought it necessary to take up the question of federal exclusivity. First, he might have thought the federal preemption rationale articulated earlier in his opinion unconvincing or erroneous; indeed, he may have included that line of argument only to assemble a majority of Justices behind his opinion. ${ }^{42}$ Second, he might have thought the exclusively federal power to legislate upon the fugitive slave problem to be of essential importance in understanding the constitutional response to the slavery problem. The question of federal exclusivity might then "remain" not in the sense that it was necessary to decide whether the Pennsylvania statutes challenged in Prigg were unconstitutional, but rather in the sense that it was necessary to understand why the Constitution prohibited those statutes. Whatever Story's reason for taking up the question of federal exclusivity, he accords it far more space and thought than he does the earlier discussion of federal preemption. ${ }^{43}$

${ }^{10}$ Id. at 618-22. Story's opinion is widely regarded as precluding recourse to state offcials for enforcement of the Fugitive Slave Act. Such was its apparent effect. See the discussion in note 69 below. Nonetheless, the language of Story's opinion is rather guarded when it comes to the subject of state magistrates' responsibilities under the Act.

11 Id. at 622 .

\$2 See Currie, First Hundred Years at 245 (cited in note 22); see also Newmyer, Justice Joseph Story at 374-75 (cited in note 21 ).

${ }^{43}$ For further thoughts on the relation between the preemption and exclusivity arguments, see note 78 .

The preemption and exclusivity questions raised by the fugitive slave clause bear a certain formal resemblance to the preemption and exclusivity questions raised by the commerce clause, U.S. Const. art. I, $\S 8$, which, like the fugitive slave clause, implicated fundamental and divisive political issues. See, e.g., Robert G. McCloskey, The American Supreme Court 68-71, 86-88 (1960). Nonetheless, important differences between the two clauses make it unwise to draw conclusions from the resemblances between the jurisprudential questions arising under each of them. There was in the debate over local power to control commerce no analogue to the questions raised by the dispute over the moral status of slavery. The battle between national and state power was of ambiguous significance within the context of the struggle over slavery: both slaveholders and abolitionists could rally beneath the banner of states' rights, depending upon which state laws were in question. The words of the clauses 
First, Story argues, because the right to recapture escaped slaves is a "new and positive right," deriving its "whole validity and obligation exclusively from the Constitution of the United States" and not from any pre-constitutional "matter of strict moral, political, or international obligation or duty" binding upon the states, that new and positive right must be uniform across the area governed by the Constitution. That uniformity is possible only if the right is enforced by federal legislation unmodified by state legislation. ${ }^{44}$

Second, "the nature of the provision and the objects to be attained by it, require that it should be controlled by one and the same will, and act uniformly by the same system of regulations throughout the Union." As we have seen, the objects of the fugitive slave clause are twofold. At a most superficial level, the clause aims to secure slaveholders' rights to regain possession of their escaped slaves. At a deeper level, the object of the clause is to facilitate the formation and preservation of the Union. The nature of the fugitive slave clause is that of a compromise: acceptance of the first, superficial object secures the second, deeper object. Story makes it quite clear that in referring to the "nature and objects" of the fugitive slave clause, he refers at least as much to the deeper as to the superficial purpose:

It is scarcely conceivable, that the slaveholding states would have been satisfied with leaving to the legislation of the nonslaveholding states, a power of regulation, in the absence of that of Congress, which would or might practically amount to a power to destroy the rights of the owner.4

Put otherwise, if the power to legislate upon the fugitive slave problem were not exclusively federal, the fugitive slave clause would not succeed in holding together the Union.

The problem, recognized by the authors of the Constitution, is that if "the states have a right, in the absence of legislation by congress to act upon the subject, each state is at liberty to prescribe just such regulations as suit its own policy, local conven-

governing commerce and fugitive slaves reflect the differing political content of the disputes over commerce and slavery: the commerce clause is permissive ("The Congress shall have Power. . To regulate Commerce among the several States. . ."), while the fugitive slave clause is restrictive (requiring both that persons held to labor in one state and escaping into another not be discharged by consequence of the laws of the other, and also that such persons be delivered up when a claim is made).

41 Prigg, 41 U.S. at 622-23.

${ }^{4}$ Id. at $623-24$. 
ience, and local feelings." 46 This statement of the problem suggests that if the fugitive slave controversy is committed to federal care, federal laws will or at least might reflect something other than local policy, convenience and feelings. One possibility is that the local policy, convenience, and feelings of the Southern states will be included together with, or added to, the local policy, convenience and feelings of the Northern states to form some sort of national policy, convenience, and feelings. A second possibility is that federal law could or would address the "public good" rather than "convenience and feeling." We have seen, however, that the state of slavery is a mere "municipal regulation," founded upon interest and convenience rather than upon the public good. Does this conclusion imply that any fugitive slave law must likewise be a mere municipal regulation? We must put this point aside for the moment, but it is worth noting that the exclusivity of federal power over the fugitive slave controversy implies that Congress could, either by not legislating or by legislating restrictively, greatly hamper the ability of slaveholders to recapture escaped slaves. Federal exclusivity is therefore a two-edged sword, not necessarily supportive of slavery, which brings the question of slavery and the future of slavery squarely within the ambit of national political discourse.

Story concludes his opinion by emphasizing that his finding of federal exclusivity does not bar states from restraining or otherwise dealing with runaway slaves to promote public peace. A state's power to secure peace is part of its general police power, which stems from its sovereignty. As such, it is entirely separate from the federal power to regulate the right to repossess escaped slaves, a right which (Story repeats for the benefit of any who might still have overlooked the point) does not emanate from the nature of sovereignty but rather from the positive declarations of our particular Constitution. ${ }^{47}$

\section{Modern Criticisms of Story's Opinion in Prigg}

Justice Story's judgment that his opinion in Prigg was a "triumph of freedom" was shared by his son and by the late Chicago political scientist Herbert Storing, but has by in large been rejected both by Story's contemporaries and by modern commentators. ${ }^{48}$ This comment addresses three recent jurisprudential and

4 Id. at 623 .

47 Prigg, 41 U.S. at 625.

48 Story, 2 Life and Letters at 392 (cited in note 1). For the opinions of Story's son and Storing, see id. at 391-98, and Storing, Slavery and the Republic at 218 (cited in note 3). 
ethical critiques of Story articulated by Ronald Dworkin, R. Kent Newmyer, and Robert Cover. These critics charge Story either with applying an incorrect method of constitutional interpretation, or with interpreting the Constitution correctly but failing to recognize a higher duty to ignore or override constitutional requirements. ${ }^{49}$ While a cogent answer to these critics will, of course, not entirely suffice to vindicate Story's opinion in Prigg, the arguments of Dworkin, Newmyer, and Cover are noteworthy both because they provide well-developed examples of modern dissatisfaction with Story's jurisprudence, and because they serve as excellent foils for the exposition of Story's thought.

\section{A. The Jurisprudential Criticisms}

Ronald Dworkin and R. Kent Newmyer direct at Story a jurisprudential criticism: they argue that Story's opinion in Prigg was misguided because Story adopted, and indeed lived in an age dominated by, incorrect or naive theories of legal interpretation. In particular, both Dworkin and Newmyer criticize Story for misunderstanding the place of moral judgments in judicial decision making.

In a review of Robert Cover's book on the American judiciary's treatment of slavery law, Dworkin argues that antislavery judges, including Story, generally failed to see that they could, consistently with their duty as judges, protect the rights of escaped slaves by developing a rights-based theory of law. According to Dworkin, a "failure in jurisprudence" was the apparent source of much of Story's difficulty, as Story failed to recognize that the "debate between natural law and positivism. . squeezed out a third theory of law according to which the rights of the slaves were as much institutional, and much more the responsibility of judges to protect, than the national politics of appeasement."

Story's modern critics are discussed in the remainder of Section II. For references to criticism from his contemporaries, see, e.g., Morris, Free Men All at 105 (cited in note 6).

40 Story has also been attacked recently on doctrinal grounds. See Currie, First Hundred Years at 241-45 (cited in note 22).

so Ronald M. Dworkin, The Law of the Slave-catchers, Times Literary Supplement 1437 (December 5, 1975) ("Law of the Slave-catchers"). This third theory is apparently Dworkin's own, which combines institutional and philosophical considerations by requiring that interpretations of existing law be judged both on the basis of fit (that is, the extent to which the interpretation may be reconciled with past law) and of justification (that is, the extent to which the interpretation accords with important political values). Dworkin lays out his theory of law most concisely in Ronald M. Dworkin, Law as Interpretation, in W.J.T. Mitchell, ed., The Politics of Interpretation 249 (1983). For a newer version of the theory, see Ronald Dworkin, Law's Empire (1986), wherein Dworkin makes his theory of legal inter- 
In Dworkin's view, Story and the other American judges who decided slavery cases refused to resolve them on the basis that slavery contravened natural law because "the judges, as a matter of legal philosophy, rejected the idea of natural law entirely." The Their rejection of natural law left the judges in a difficult position, since the positive law regarding slavery was "unsettled" and did "not dictate a decision one way or another." The judges therefore had "[n]o other source of law to which [they might] turn," and so had to "exercise their discretion to develop the law as their sense of justice or policy suggest[ed]." Dworkin thus argues that an explanation of Prigg and other slavery decisions depends upon discovering why the judges, "[i]f they believed that they had to exercise a legislative discretion to make new law, . . . believed that they had to make new law that they thought was immoral. . . ."52

Story and the other judges faced a choice, in Dworkin's reading of their predicament, between legal rules that advanced "whatever policies the ... Constitutional Convention and the Congress . . . had set in train," and legal rules that protected "individual right against misguided public policy." Dworkin contends that the judges rejected the latter alternative because they perceived their choice as one between a public conception of policy and a private conception of rights:

The rights in which they believed were accepted locally, but they were also the subject of a national political controversy. ... . [The judges] saw, on one side of the legislative scales, a policy that could be called public because it had been embodied in a constitutional provision and a series of national statutes. [They] found, on the other side, a passion, that, however fervent, [they] could not count as public but only as personal. ${ }^{\mathrm{s}}$

Dworkin claims that the judges faced this choice only because they

pretation depend upon his claim to identify a new political value, "integrity," which must take its place alongside justice, fairness, and equality. See id. at 164-67, 176-275.

${ }^{81}$ Dworkin, Law of the Slave-catchers at 1437. This particular assertion of Dworkin's is entirely unfounded in either Story's work or Cover's depiction of Story and his colleagues. Nonetheless, Dworkin's criticism remains worthy of attention because it may be possible to reformulate Dworkin's arguments in ways that do not depend upon the assertion that Story rejected the idea of natural law. See text accompanying note 55 .

${ }^{82}$ Id. at 1437.

${ }^{63}$ Id. It may at first seem difficult to reconcile Dworkin's view that the law was unsettled with his claim that judges perceived a clear public policy. However, Dworkin's position remains comprehensible if the unsettled state of the law results from uncertainty about the extent to which higher law principles modify a clear positive law policy. 
had abandoned a theory of law that had "dominated the Supreme Court, in the person of John Marshall, years before the slavery cases, just as it was to dominate the Conservative Court of the early 1930's and the Warren Court of the 1960's." On this theory,

the law of a community consists not simply in the discrete statutes and rules that its officials enact but in the general principles of justice and fairness that these statues and rules, taken together, presuppose by way of implicit justification. The general structure of the American Constitution presupposed a conception of individual freedom antagonistic to slavery, a conception of procedural justice that condemned the procedures established by the Fugitive Slave Acts, and a conception of federalism inconsistent with the idea that the State of Massachusetts had no power to supervise the capture of men and women within its territory. These principles were not simply the personal morality of a few judges. . . . They were rather, on this theory of what law is, more central to the law than were the particular and transitory policies of the slavery compromise. ${ }^{.4}$

We may summarize Dworkin's criticism of Story and Story's contemporaries, and abstract from some of Dworkin's historically unfounded assertions, as follows. Nineteenth century jurists in general recognized that law interacted with moral considerations only in the form of natural law, which, according to Dworkin, was regarded as a "body of law that exists by virtue of objective morality rather than the positive enactments of legislatures or other human agencies."'5s While some jurists thought that natural law considerations should sometimes trump positive legal rules or apply where positive legal rules were indeterminate, Story and his colleagues agreed that the positive, humanly enacted law had to be interpreted by reference to legislatively declared public policy preferences rather than by reference to moral judgments. Story's jurisprudence erred by confining moral considerations to the province of natural law and so overlooking the relevance of moral principles to the interpretation of positive law.

Newmyer, in his sustained scholarly biography of Story, criticizes Story from a perspective radically different from Dworkin's. Like Dworkin, Newmyer believes that nineteenth century jurisprudential thought blinded Story to the most accurate understanding 
of judicial reasoning:

[Story's jurisprudence] must be understood as the creation of a unique moment in American history or, more precisely, as the singular commingling of history and biography. . . . If he was passionately confident in what he did, it was because the age invited such faith in the works of reason; if there was a unity to his life's work, it was in no small part because the culture of the early republic was itself integrated. ${ }^{\mathbf{6}}$

Again like Dworkin, Newmyer criticizes Story's jurisprudence as misunderstanding the way in which moral choices and political interests necessarily inform legal doctrine. According to Newmyer, this flaw in Story's thought was rendered most apparent by the slavery problem:

[Story] did not perceive that abolitionist constitutionalism, which culminated in the Civil War amendments, might be the cutting edge of a new admixture of morality and law, that in a segmented and unequal society lawmakers might have to choose social justice over legal science and perhaps even property rights. ${ }^{57}$

Unlike Dworkin, however, Newmyer does not attribute Story's errors to a failure to make adequate recourse to moral theory. Newmyer instead identifies at least three distinct factors that led Story to make what Newmyer views as jurisprudential mistakes. First, Story exaggerated the extent to which rationality could overcome moral conflict. According to Newmyer,

With Thomas Jefferson, Story shared the fundamental belief that mankind could be studied scientifically, that the complex problems of human government would yield to the science of government of which legal science was but a part. Story's system of American law was grounded in the rationalism of the eighteenth century. Many years ago Carl Becker taught us how idealistic, how romantic, this new "heavenly city" was.

Second, Story's jurisprudence lacked a "self-critical perspective": "Skepticism was not one of his intellectual qualities; speculation

${ }^{86}$ Newmyer, Justice Joseph Story at 386-87 (cited in note 21). Two paragraphs later Newmyer adds that "[e]ven the absence of self-criticism in Story's system is largely attributable to the age, which, perhaps because it was so anxious, dealt in absolutes so easily." Id. at 387. Similarly, Newmyer elsewhere observes that the "age that encouraged Story to build nobly doomed his noble system to impermanence." Id. at 391.

${ }^{87}$ Id. at 390. Newmyer is highly critical of Story's disposition of Prigg. Id. at 370-78. 
was positively anathema; and the anthropological curiosity that permeates Holmes' Common Law was not even hinted at. Certitudes bristled at every turn." Third, Story underestimated the difficulties that hindered achievement of a republican American community "united in purpose, values, and beliefs." According to Newmyer, Story mistook the "centrifugal forces that eroded the foundations of republican community" for a "decline in morality," when in fact the forces were "inevitable consequences of demography or economics or social history." These three factors culminated in Story's failure to "question the intellectual and historical premises on which he operated," and, in particular, his refusal to acknowledge the possibility that the Constitution might be founded on an attempt to secure the interests of particular classes rather than on a commitment to pursue lofty republican goals. ${ }^{58}$

While Newmyer's criticism of Story goes to the core of Story's thought and implies that Story's jurisprudence is inapplicable to the modern era, it is notably respectful of the Justice. Story's failings are not, in Newmyer's view, misunderstandings that might have been corrected by "progress" in moral theory. Rather, Newmyer attributes those failings at least partly to the urgency of the circumstances in which Story operated:

Story was so busy thinking about how law might be harnessed to the needs of a republican people that he had no time or inclination to think about thinking. Jurisprudential self-consciousness was a luxury reserved for a later age, an age when growing complexity generated skepticism (and curiosity) and swamped easy answers in intellectual relativism.

Newmyer later observes that "it is unlikely . . . that Story could have built so well had he doubted more." Story cannot in Newmyer's view be criticized either for failing to realize that judging was part of governing, or for failing to govern responsibly. "As long as Story lived, he struggled to make American society rational, equitable, and moral."so

s8 Id. at $386-390$.

s9 Id. at 387,390 , 391. For a somewhat less sympathetic, although still tempered, criticism of Story from the perspective of legal realism, see Morgan D. Dowd, Justice Joseph Story: A Study of the Legal Philosophy of a Jeffersonian Judge, 18 Vand.L.Rev. 643 (1965) ("When Story arrived on the bench the law of reason school was already on the decline and the era of historical jurisprudence beginning. Nevertheless, many of the weaknesses of eighteenth-century rationalism can be found in Story's writings"). 


\section{B. The Ethical Criticism}

Unlike Dworkin and Newmyer, Robert Cover criticizes Story on ethical rather than jurisprudential grounds. Cover argues that Story's opinion in Prigg is wrong because Story compromised his own moral principles to enforce an immoral constitutional provision. This argument contends not that Story incorrectly read the Constitution, but that Story incorrectly allowed the Constitution to govern his disposition of the case. Undergirding this argument is the premise that the Constitution was, in Story's time, a profoundly proslavery and thus profoundly immoral document.

No brief summary can do justice to Cover's work, but it is possible to set out the basic elements of his criticism of Story. According to Cover, the antislavery judges (including Story) of the nineteenth century confronted what Cover calls a moral-formal dilemma: the issue, in the view of these judges, was "whether the moral values served by antislavery (the substantive moral dimension) outweighed interests and values served by fidelity to the formal system when such values seemed to block direct application of the moral or natural law proposition." were left with a choice between abandoning their moral responsibilities or their institutional responsibilities. ${ }^{61}$

In articulating more fully the nature of this moral-formal conflict, Cover does not assume that moral considerations could never influence judicial decision making in ways that were, in the judges' own view, institutionally legitimate. On the contrary, he contends that judges expressed moral requirements in terms of natural law, and that they recognized a place for recourse to this natural law in judicial reasoning. According to Cover, "[i]n the natural law tradition on slavery, the judge inherited a device for expressing the gap between the law as it is and the law as it ought to be." Moreover, "[t]he judge's natural law heritage was not mere rhetoric, speculation and polemic. While the day-to-day work of slave law rarely turned on the 'natural law' of slavery, there were exceptions." Natural law might have "grave significance" in "conflict-of-law cases-cases where a court must decide on the extraterritorial effect to be given a master-slave relationship created by the law of a foreign sovereignty," and there was a possibility that in instances "where neither statute nor custom provided guidance, recourse to

${ }^{80}$ Cover, Justice Accused at 197 (cited in note 21).

61 Dworkin rejects this formulation of the judges' predicament, believing instead that the judges' moral and institutional responsibilities were compatible. Dworkin, Law of the Slave-catchers at 1437 (cited in note 50). 
first principles might be appropriate."62

On Cover's account, nineteenth century judges took a positivist view of the sources of legal authority but thought that natural law might be a source for the content of positively enacted law. While judges at times might refer to natural law, the institutional responsibilities of the judiciary imposed strict limits upon the legitimate scope of such references:

[T] he judge . . . inherited a tradition binding him to the explicit sources of law. Constitutions were the highest examples of such explicit law. In their written form they justified judicial review precisely because they were positive law. The notion that out beyond lay a higher law to which the judge qua judge was responsible was never a part of the mainstream of American jurisprudence.

This "tradition of positivism meant the judge ought to be will-less. Responsible judging has no element of the personal preferences of the magistrate."

Cover argues that as positivism gained in intellectual prominence through the course of the nineteenth century, it not only limited the role-abiding judges' ability to decide cases according to natural law principles, but it also eroded natural law's claim to express an objective, true moral view. According to Cover, "judicial recourse to 'natural law' . . . was to sound less and less like an appeal to commonly accepted sources for principle and more and more like a party slogan." As a result, "from 1780 to the eve of the Civil War, the natural law condemnation of slavery came to mean not a common cultural tradition but a personal (or at least, party) preference." $" 64$

The constraints on recourse to natural law and the progressive erosion of natural law combined to limit the situations where judges might use such principles to decide cases. According to Cover,

Throughout the sixty year period following the Revolution, most judges and lawyers would have conceded the sense and validity of the pair of statements: (1) natural law has a place in our legal system; and (2) slavery is no creature of natural

${ }^{62}$ Cover, Justice Accused at 29 (cited in note 21). By the phrase "natural law tradition," Cover refers to both the content of natural law and also the practice of making reference to natural law in judicial reasoning.

os Id. at 29.

or Id. at 29-30. 
law, but of municipal law in conflict with natural law.

Nonetheless,

[C]ourts uniformly recognized a hierarchy of sources of law for application in which "natural law" was a subordinate to constitutions, statutes, and well-settled precedent. ... The reason for natural law's subordinate place was a thoroughgoing positivism concerning the origin of "law."

Yet this did not preclude the belief that natural law might be a source of law's content; that is, the particular laws enacted by valid processes might, in the absence of evidence to the contrary, be presumed to enact natural law principles. Courts had applied this interpretive assumption in some cases to support, in an "imprecise and cautious" fashion, a preference for liberty. ${ }^{65}$

Despite the possibility that positivist courts could recognize natural law in legislation, moral-formal conflicts are in Cover's model of natural law inevitable, for that model regards natural law as inconsistent with practical compromise. Although Cover never makes this point at length, his view that practical compromise is inconceivable under nineteenth century understandings of natural law surfaces at various instances in his discussion. Perhaps the most revealing instance occurs in a passage where Cover interprets a letter from John Adams to Jeremy Belknap, a recording secretary for the Massachusetts Historical Society. In the letter, Adams responds to a suggestion made by the prominent American legal scholar St. George Tucker that, with respect to slavery, the maxim, "fiat justitia, ruat coelum" [let justice be done, though the heavens fall], described the proper course of action. Adams wrote to Belknap,

If I should agree with him in this maxim . . . the question would still remain, what is justice? Justice to the Negroes would require that they should not be abandoned by their masters and turned loose upon a world in which they have no capacity to procure even a subsistence. What would become of the old? the young? the infirm? Justice to the world, too, would forbid that such numbers should be turned out to live by violence, by theft, or by fraud. ${ }^{66}$

${ }^{38}$ Id. at 39, quoting Letter from John Adams to Jeremy Belknap, Oct. 22, 1795, in Letters and Documents Relating to Slavery in Massachusetts, in 3 Collections of the Massachusetts Historical Society 416 (5th Ser. 1877). 
Cover follows this quotation from Adams with the interpretive comment that Adam's statement means that "[i]n short, justice is not natural; it is a concept whose very meaning is given only in societal contexts." "87

Cover's comment appears to rest on a non sequitur, for justice may in fact be at once both contextual and natural. To take a simple example, as a matter of natural law war may be a bad thing and peace may be a good thing, without in any way undermining the proposition that declaring war under some circumstances is not only in accord with but required by natural law. ${ }^{68}$ To make the same point from another angle, saying that justice depends upon societal context is not equivalent to saying that justice is entirely the product of societal norms. Justice may depend heavily upon factual detail, and be difficult to specify apart from context, without being simply a reflection of the values of the people who inhabit each particular context. We may certainly dispute John Adams' evaluation of the contextual significance of justice, or his prediction of the consequences of emancipation, but the problem with his argument is not that it abandons natural in favor of societal justice. How, then, are we to make sense of Cover's critique? Only if we supply Cover with an unspoken premise: natural law takes the form of a set of universal prohibitions or commandments (e.g., never do anything that enslaves anyone or facilitates the continuation of slavery). If natural law, and natural justice, must have a universal form, then a contextual formulation of justice is properly regarded as non-natural. Of course, such a form of natural law is manifestly inconsistent with practical compromise: "never" means never.

If natural law conflicts with practical compromise, the fugitive slave laws, as products of practical compromises among established interests for and against the unnatural institution of slavery, were precisely the sort of regulations likely to give rise to the moralformal dilemmas Cover describes. Prigg v. Pennsylvania raised a particularly acute dilemma, for the antislavery bar had come to rely heavily on the Northern statutes that Story found unconstitutional. Story's decision supporting national power therefore represents, for Cover, an abdication of Story's moral, natural law commitment to antislavery ideals in favor of adherence to the formal requirements of positivist jurisprudence. ${ }^{68}$

6r Cover, Justice Accused at 39 (cited in note 21).

68 See, e.g., Michael Walzer, Just and Unjust Wars (1977).

69 Cover, Justice Accused at 161, 166, 240-241 (cited in note 21). Cover qualifies his 


\section{The Natural Law Foundations of Story's Opinion in Prigg}

What, if anything, can be said in defense of Story's own proclamation that his opinion in Prigg was not misguided, jurisprudentially or ethically, but was rather a "triumph of freedom?" This Section and the one that follows argue that careful attention to the natural law foundations of Story's opinion vindicates Story's judgment and successfully answers the claims of modern critics. In brief, the argument is that, according to Story, the Constitution aimed to create not merely a free North, or a collection of states partly free and partly slave, but rather a free Union. In order to effectuate this purpose, the Constitution had to accommodate and include both the recognition that slavery was immoral and also the means sufficient to keep the Union together until the federal government could eliminate slavery. As such, the Constitution reflected both a natural law judgment and a pragmatic concession to the exigencies of power and interest. This dual character of the Constitution is itself entirely consistent with, and perhaps even demanded by, natural law. As a result, any sound interpretation of the Constitution must attend both to its ethical purposes and to its practical compromises. I intend not only to demonstrate that Story espoused this view of the Constitution, but also to provide reasons why this view may in fact be correct. ${ }^{70}$

Justice Story himself never explicitly applied his natural law science to the American slavery problem. ${ }^{71}$ This Section therefore

evaluation of Story's decision because he is unsure whether the explanation for the decision given by William Story provides an adequate moral argument in favor of the decision. William Story argues that his father intended to strike a practical blow to the recovery of fugitive slaves by requiring slavechasers to seek out hard-to-find federal officials rather than the more accessible state magistrates. Story, 2 Life and Letters at 393-94 (cited in note 1). For one commentary upon this argument, see Paul Finkelman, Prigg v. Pennsylvania and Northern State Courts: Anti-slavery Use of a Pro-slavery Decision, 25 Civil War Hist. 5 (1979) (arguing that Prigg was a pro-slavery decision and that the Constitution is a proslavery compact, but that anti-slavery forces in the North successfully put the decision to anti-slavery uses). Cover declines to take a side in this debate on the ground that empirical evidence is lacking. Yet, as R. Kent Newmyer points out, even if Prigg initially made the recapture of fugitives harder by requiring recourse to federal officials, it also authorized Congress to do what it did in 1850: enact a much more stringent fugitive slave law. Newmyer, Justice Joseph Story at 376 (cited in note 21). The defense of Justice Story's opinion against Cover's ethical criticism must therefore rest on some ground other than the claim that Story's opinion deprived Southern slavechasers of recourse to state officials.

${ }^{70}$ As noted earlier, this line of argument generally follows that of Storing, Slavery and the Republic at 214-33 (cited in note 3).

${ }^{71}$ Story's Commentaries on the Constitution include only two brief paragraphs on the fugitive slave clause. Story, 3 Commentaries on the Constitution at \$§ 1805-06 (cited in note 
attempts to explain Story's treatment of the slavery question in Prigg by interpreting Story's general reflections upon natural law and jurisprudence. ${ }^{72}$ The next section applies that interpretation to the fugitive slave clause. The rather lengthy interpretive argument that follows seeks to answer, more particularly, four questions. First, what sense can be given to the idea of a "peculiarly positive" right? Second, what is the difference between a municipal regulation and other laws, and what help, if any, does a proper understanding of this difference provide to the task of interpreting the fugitive slave clause ? $^{73}$ Third, does Story's jurisprudence overlook either (as Dworkin suggests) the possibility of a jurisprudence more closely tied to moral philosophy or (as Newmyer suggests) the need for a jurisprudence capable of passing critical judgment upon the substantive moral and political premises of American constitutionalism? Fourth, does there exist (contrary to Cover's argument) an ethical, as well as an institutional, justification for Story's opinion in Prigg?

\section{A. Natural Law Questions Raised by Story's Doctrinal Analysis}

The natural starting point for a defense of Story's opinion in Prigg is the text of that opinion itself. Reflection upon that text reveals that Story's analysis of federal exclusivity depends in two respects upon his understanding of natural law. To repeat briefly the relevant parts of Story's argument, the fugitive slave clause aims to secure from delay or frustration by Northern states the rights of Southern slaveholders to recapture escaped slaves. The deeper purpose animating the clause is the preservation of the Union; unless the clause adequately enforces the claims of slaveholders, the Union cannot exist. Since slavery is a mere "municipal regulation," however, there exists no pre-constitutional moral or political duty to respect the claims of slaveholders. The Constitution thus created a new right, one that was exclusively federal: since the new right owes its existence to a single document, the right has to be uniform everywhere that document applies and, much more importantly, if the new right were not exclusively federal, the right would not effectuate the Union-preserving purposes of the clause.

21). The paragraphs are entirely consistent with Story's opinion in Prigg, but shed no light on the general theoretical issues discussed in this comment.

72 This interpretation assumes that Story's view of natural law was largely consistent over time. I have found no evidence to contradict this assumption.

7s These two questions arise out of Story's doctrinal arguments. See Section III.A. 
As even this brief summary makes clear, Story's argument turns upon the view that the fugitive slave clause was unique because it sought to address an interstate conflict so virulent that it could have dissolved the Union. There may be, however, a second, equally fundamental basis for Story's reading of the fugitive slave clause. Slavery, according to Story, is "repugnant to the natural rights of man and the dictates of justice." It is "to be lamented . . . that slavery exists in any part of our country."74 The persistence of slavery is therefore a problem for the Union. While Story is relatively silent in Prigg about this aspect of the slavery problem, his interpretation of the fugitive slave clause does bring the fugitive slave problem, and with it slavery, within the ambit of national political discourse. Moreover, Story's opinion may plausibly be interpreted to hold that federal legislation upon the fugitive slave question is preferable to state legislation because federal legislation aims at something other than "feeling and convenience." Finally, if Story did believe that one, somewhat hidden, purpose of the fugitive slave clause was to permit federal resolution of the slavery problem, Story had a good reason to be discreet about that purpose, since explicit mention of it might well have fueled precisely the sort of Union-dissolving conflict Story sought to avoid. While Story's opinion may withstand scrutiny even if the fugitive slave clause does not aim to bring the slavery problem within the confines of national political discourse, this second deeper purpose makes Story's answer far more cogent, for it provides another reason why the Constitution might demand federal exclusivity rather than permitting "conscientious efforts" by states to return fugitives to claimants while "protecting the rights of [their] free black populations."76

Story's reasoning in Prigg thus depends crucially upon the validity of Story's view of the purposes of the fugitive slave clause, and Story's view of those purposes in turn depends for its intelligibility and verity on Story's understanding of the relationship between natural and positive law. Story's argument implicates this relationship in two ways. First, when he asserts that Congress must legislate upon the fugitive slave problem and when he develops the first of his two reasons for exclusivity, Story emphasizes the peculiarly positive character of the property right granted to slavehold-

74 Story, Piracy and the Slave Trade at 136-37 (cited in note 21).

${ }^{75}$ See text accompanying notes 45-46.

${ }^{76}$ Currĩê, First Hundred Years at 243 (cited in note 22). 
ers. ${ }^{77} \mathrm{~A}$ right can be peculiarly positive only if it is distinguishable from some other sort of less positive or less purely positive right. Moreover, this particular right must be distinguishable from these other less positive rights in a way that does not undermine its own binding validity. Second, the textual basis within Story's Prigg opinion for ascribing to the fugitive slave clause an antislavery purpose, that of committing the slave problem to Congress for national resolution, consists entirely of enigmatic assertions that local slavery statutes depend upon local policy, feeling, and convenience, and that slavery is a municipal regulation. These assertions are enigmatic because they force us to consider what other, unarticulated foundations for law and forms of law exist. The relationship between natural and positive law is therefore of crucial importance not only to answering the jurisprudential and ethical criticisms of Story's work, but also any doctrinal criticisms of that work. ${ }^{78}$

\section{B. Joseph Story's Science of Natural Law}

Story's only sustained examination of natural law is an eightpage article, published anonymously in Francis Lieber's Encyclopedia Americanae. ${ }^{79}$ This article, like almost all of Story's less technical essays, has received almost no scholarly attention. ${ }^{80}$ This is understandable, since Story himself viewed his speeches, articles, and casual essays as less serious undertakings than his several treatises on American law, but these speeches, articles and essays provide the only repository of Story's thoughts about the relationship between law and broader ethical and intellectual concerns. As such, these works cannot be ignored when critics implicitly or ex-

77 Prigg, 41 U.S. at 622-23.

78 Left unvindicated, however, is Story's federal preemption argument. As noted above, Story devoted considerably less attention to the preemption argument than to the exclusivity argument. It is plausible that the preemption argument is the cement that held together a precarious majority that might, in the absence of the argument, have openly rejected the more constitutionally powerful exclusivity argument. As Newmyer observes, it is not obvious how many of the nine Justices embraced Story's exclusivity doctrine. Newmyer, Justice Joseph Story at 374-75 (cited in note 21 ).

79 Joseph Story, Natural Law, in Francis Lieber, ed., 9 Encyclopedia Americana 150-58 (1832) ("Natural Law"). There is very little doubt that Story in fact authored the article. For a discussion of the evidence, see John C. Hogan, Joseph Story's Anonymous Law Articles, 52 Mich.L.Rev. 869 (1954). See also Newmyer, Justice Joseph Story at 275 (cited in note 21). Story's article is reprinted in James McClellan, Joseph Story and the American Constitution 313-24 (1971) ("Story and the Constitution").

${ }^{80}$ A significant exception is McClellan, Story and the Constitution (cited in note 79). McClellan devotes an entire chapter to Story's view of natural law, and discusses in some detail the Encyclopedia article. See id. at 66-68. McClellan's interpretation is, however, radically inconsistent with the arguments of this comment. 
plicitly question the philosophical foundations of Story's thought. In this subsection I offer an interpretation of Story's article on natural law. ${ }^{81}$ This interpretation argues that the key to Story's natural law science is its description of the particular relationship among the ideas of happiness, virtue, and "ultimate (or permanent) happiness." That relationship provides the foundation for a science of natural law that is more practical and contextual than Cover's version of natural law. As such, Story's account of the relationship between happiness and virtue provides a basis for answering Cover's ethical critique as well as justifying the Constitution's practical concessions to proslavery interests.

Subsection 1 below examines the basic conceptual framework of Story's understanding of natural law. Subsections 2 and 3 then take up important subtopics: the relation of natural law to theology and philosophy, and the relation of natural law to positive institutions. While what emerges is a rather full portrait of Story's theory of natural law, certain aspects of that portrait deserve special notice, since they overcome certain modern prejudices against natural law. First, Story's version of natural law does not depend upon divine revelation. Second, Story's version of natural law does not prescribe, or presume the existence of, a fixed and acultural set of moral rules. Third, Story's version of natural law is not inflexible or otherwise insensitive to the demands of practical politics.

1. The Character of Natural Law. Story begins his article by discussing the content of and assumptions appropriate to the theory of natural law. Story's first sentence defines natural law:

Natural law, or, as it is commonly called, the law of nature, is that system of principles, which human reason has discovered to regulate the conduct of man in all his various relations. ${ }^{82}$

Story's definition contains a remarkable ambiguity. This ambiguity arises because the word "regulates" may have at least two meanings: it could mean "prescribes what is right and wrong" (i.e., "measures"), or "determines the character and limits of" (i.e., "controls," as physical forces do), or both. When Story contends that natural law regulates human action, does he mean that, as a matter of fact, it does govern human action, or that, if men were just, it would do so? Story's definition admits the possibility of a prescriptive or a descriptive science of natural law. If natural law

${ }^{81}$ Because the article may be difficult for some readers to find, I will to the greatest extent possible quote in their entirety the passages that $I$ interpret.

82 Story, Natural Law at 150 (cited in note 79). 
includes a prescriptive component, it could serve as a more or less comprehensive (including some matters not regulated by positive law, and excluding other matters within the scope of positive law) and more just alternative to the rules of the positive law. According to this view, natural law would be a set of rules like those that comprise the positive law, rules telling citizens what to do.

On the other hand, if natural law were a descriptive science, one that revealed the tendencies and elements of human character and conduct, that science would include certain rules or principles that, while they might well help one to tell right from wrong, and while they would certainly assist someone drafting the positive law, could not simply substitute for the positive law. Recognizing this ambiguity in Story's definition of natural law is important to understanding Story's jurisprudence. In addition, this recognition allows one to compare Story's ideas with Cover's, since Cover's characterization of natural law as a way to express the gap between what the positive law is and what it ought to be applies only insofar as natural law is a prescriptive science. ${ }^{83}$

The second and third sentences of Story's article preserve the ambiguity of the first sentence, as they continue to present natural law as a science that might be prescriptive, descriptive, or both.

Doctor Paley defines [natural law] to be the science, which teaches men their duty and the reasons of it. In its largest sense, it comprehends natural theology, moral philosophy, and political philosophy; in other words, it comprehends man's duties to God, to himself, to other men, and as a member of political society. ${ }^{84}$

If natural law teaches men not only their duties but the reasons for those duties, natural law is at least partly descriptive. Nonetheless, this seeming resolution of the ambiguity raised in the first sentence is imperfect since, rather than endorsing the opinion presented in the second sentence, Story attributes it to Paley. By attributing

ss The ambiguity in Story's definition reappears in another essay in which Story defines natural law: "The law of nature is nothing more than those rules which human reason deduces from the various relations of man, to form his character, and regulate his conduct, and thereby insure his permanent happiness." Joseph Story, The Value and Importance of Legal Studies, in William W. Story, ed., The Miscellaneous Writings of Joseph Story 503, 533 (1852) ("The Importance of Legal Studies"). The definition in Story's essay on legal studies seems, however, to favor a prescriptive view of natural law, since the rules in question insure man's permanent happiness. However, since the rules are deduced from man's "various relations," the science of natural law is apparently inseparable from, even if distinct from, the descriptive science of human conduct.

s4 Story, Natural Law at 150 (cited in note 79). 
the claim to Paley, rather than making the claim himself, Story may either seek authority for his own belief, or may wish to refer to a common opinion which he himself disavows-the author of an encyclopedia article may have special reasons for mentioning common opinions which he does not hold. ${ }^{85}$ Similarly, saying that natural law comprehends various things does not imply that it comprehends only those things.

Story's ninth sentence is perhaps the most crucial one of the article, as it sets out the assumptions fundamental to Story's science of natural law. In so doing, the sentence begins to resolve the ambiguity in Story's definition of that science. ${ }^{88}$ The assumptions in the ninth sentence repay careful attention (in the excerpt that follows, I have numbered Story' assumptions for later convenience):

For the purposes of the present article, we shall assume, without undertaking to prove, [1] that there is a God of infinite power, knowledge, wisdom, benevolence, justice, and mercy;

${ }^{85}$ Interpreting an encyclopedia article involves problems not encountered in analyzing most legal scholarship. For example, an encyclopedia article may aspire only to provide a reader with the background necessary to understand a debate, rather than present a particular resolution of that debate. As such the article may be at least in part a report of views other than those of its author.

Such may be the case with Story's reference to "Doctor Paley." William Paley, a late eighteenth century moral philosopher familiar to lawyers and students of Story's time, "argued for the permeation through all society of unifying Christian values." Newmyer, Justice Joseph Story at 26 (cited in note 21). See also McClellan, Story and the Constitution at 6869 (cited in note 79); Hogan, 52 Mich.L.Rev. at 882 (cited in note 79). Both McClellan and Hogan assume without argument that Story means to endorse Paley's opinion by quoting it, and McClellan indicates that other aspects of Story's article are lifted from, and so may be interpreted in light of, Paley's views. Nonetheless, since Story does not say that he accepts Paley's view, and since the author of an encyclopedia article has a special duty to acquaint his readers with common opinions about the article's subject, Story may very well have quoted Paley in order to situate the article within a contemporary debate about natural law. Story's article is full of references to common opinions which Story himself flatly rejects. See, e.g., Story, Natural Law at 155 (cited in note 79) (canvassing various views on the origin of property). Paley is, however, the only authority that Story mentions by name in the entire article. In discussing a topic that has occupied the thoughts of many a genius, Story's choice of Paley is rather peculiar if Story desires to acquaint his readers with wellreasoned ideas rather than popular thinkers. The choice is particularly odd because Story was skeptical about the value of contemporary scholarship on matters of timeless concern, preferring to trust instead the learning of the great masters. Joseph Story, Literary Tendencies of the Times, in William W. Story, ed., Miscellaneous Writings of Joseph Story, 740, 748-52, 777 (1852). This essay is a comparison of past and present (early-to-middle nineteenth century) scholarship. Paley's name is entirely absent from the essay.

B8 The fourth through eighth sentences of the article discuss the relation of natural law to God. I examine the significance of these sentences in Section IV.B.2 below. McClellan does not discuss Story's ninth sentence, apparently considering it unimportant. McClellan, Story and the Constitution at 66-67 (cited in note 79). 
[2] that he has created man with suitable powers and faculties to pursue and obtain happiness; [3] that man is a moral, dependent and accountable being; [4] that his soul is immortal; [5] that his ultimate happiness or misery is dependent upon his own conduct; [6] that there is a future state of retribution, in which the inequalities of the present life will be adjusted according to supreme wisdom and goodness; [7] that, by a right application of his powers and faculties, man may always discern and pursue his duty; [8] that virtue, or doing good to mankind in obedience to the will of God, has attached to it the reward of everlasting happiness; and [9] that vice, or doing wrong in disobedience to that will, is, by the very constitution of man's nature, necessarily connected with suffering and misery, directly or ultimately. In short, that man cannot be permanently happy by the practice of vice, and must be permanently happy by the practice of virtue. ${ }^{87}$

The form of these nine assumptions is itself revealing. The assumptions are not basic commands or rules of conduct. Rather, they are statements about the means for and consequences of attaining virtue and happiness. The assumptions are descriptive of the human condition rather than prescriptive. If these assumptions are the fundamental principles or axioms of Story's natural law science, then that science evidently has a descriptive component.

Story's nine assumptions are also rich in content. Although more could be said about the way Story's assumptions treat the ideas of happiness, virtue, and ultimate happiness, three observations stand out as particularly important. First, Story's assumptions provide for the existence of a permanent or ultimate happiness distinct from the sum of particular happinesses at particular moments. Second, under Story's assumptions, the requirements of virtue and so of natural law take notice of practical constraints on human conduct. Third, man has effective but imperfect faculties enabling him to pursue virtue and happiness. I will discuss each of these observations in detail.

The fourth, sixth, and eighth clauses of Story's sentence lay the foundation for the existence of permanent happiness, the first of the three observations. Together those clauses assert the existence of a soul, a final state of retribution, and a guarantee of everlasting happiness as a reward for virtue. Ultimate happiness appears, on Story's assumptions, to be a condition of the immortal

${ }^{87}$ Story, Natural Law at 151 (cited in note 79). 
soul rather than a mere feeling or bodily condition. This distinct sort of happiness is essential for Story's fifth clause, claiming that man's ultimate happiness depends upon his conduct. Obviously it does not, if he is cruelly treated by stronger persons all his life, unless ultimate happiness and misery are entirely separable from momentary pleasure and pain.

A second, equally important, consequence follows from the existence of an ultimate or permanent happiness distinct from momentary happiness. The dichotomy justifies what is for Story the key assumption of natural law: that the pursuit of happiness (or at least "permanent happiness") entails the pursuit of virtue, and that the virtuous man is happier than the unvirtuous. Were happiness nothing more than the sum of pleasurable sensations, it could be argued that some people, absent personal qualms, should pursue pleasure at the expense of justice. By assuming that a future state of retribution exists, Story forecloses this line of reasoning.

Although Story speaks of a future state of retribution, Story's assumptions regarding "permanent happiness" and the "future state of retribution" suggest that one may experience this state now as well as in the after-life. ${ }^{88}$ In other words, permanent or ultimate happiness may be a condition of the immortal soul that begins in the earthly, human life and continues into the after-life. Story's selection of the terms "permanent happiness" and "permanent misery" rather than, for example, "divine salvation" and "eternal damnation," is itself the clearest indication that permanent happiness can be a part of the human experience. Story thus likens the ultimate reward for virtue to the quite human (in the sense of not other-worldly or divine) experience of happiness. Permanent happiness is apparently a species of happiness, although a particularly privileged species. Story appears to suggest that although permanent happiness is distinct from momentary happiness, one can comprehend it through reflection on the more pedestrian forms of happiness.

There are other indications that permanent happiness may not be confined to the after-life. For example, Story's sixth clause asserts that inequalities will be adjusted by "supreme wisdom and goodness." Again, Story does not say "divine" wisdom and goodness. It is thus possible to read the clause as saying that an extraordinary mind, perhaps one that is human, will adjust inequalities in circumstances so as to recognize and understand the

${ }^{88}$ Story's assumption that the soul is immortal and that "everlasting happiness" is possible imply quite clearly that permanent happiness does not cease at death. 
happiness of the just, and therefore truly happy, man.

The second of the three observations is that Story's assumptions suggest that the requirements of virtue, and so of natural law, take notice of the practical hindrances imposed on human action by human interests and needs. This observation arises in part out of Story's use of the phrase "permanent happiness" to describe the reward for virtue, since happiness depends to some extent on the satisfaction of human needs. Additional support for the observation comes from the third clause. That clause, in addition to describing man as "moral" and "accountable," and so implying that man is responsible for his own happiness, asserts that man is dependent. What is this claim doing in a clause that apparently asserts man's freedom or, in a sense, independence?

Story, whose works evidence a respect for and frequently refer to Blackstone, most likely had in mind Blackstone's suggestion that a being which has both a free will and independence is subject to no law:

A being, independent of any other, has no rule to pursue, but such as he prescribes to himself; but a state of dependence will inevitably oblige the inferior to take the will of him, on whom he depends, as the rule of his conduct: not indeed in every particular, but in all those points wherein his dependance consists. ${ }^{80}$

Put very bluntly, those who are not strong enough to be independent must conform to the requirements of those who have power over them. This formulation of natural law bears a very great resemblance to "might makes right," except that here power is defined in terms of the ability to obtain happiness, and happiness is tied in some respects to what is good and right. Thus "might" in this context is not simply physical power but perhaps something like wisdom, which comprehends a knowledge of what is good and bad. Nonetheless, it is accurate to say that for both Story and Blackstone natural law is in large measure a matter of coming to terms with the problems of human needs, human fear, human weakness, and human power.

The third and final observation is that man has effective but imperfect faculties enabling him to pursue virtue and happiness. Story assumes that man has some capacity to secure his own happiness, but it is unclear how great Story believes this capacity to

89 William Blackstone, 1 Commentaries **39. Consider also Story's references to Blackstone in Story, 1 Commentaries on the Constitution at $\S \S 326,339$ (cited in note 21). 
be. In particular, Story does not indicate whether man has the capacity to secure permanent happiness. Does he mean, when he says in the second clause that man has suitable powers to pursue and obtain happiness, that man also has suitable powers to pursue and obtain permanent or ultimate happiness, which he mentions in later clauses? Story leaves that question open, for in the seventh clause he introduces a distinction between the possession of powers and faculties, and the right exercise of those powers and faculties. Unless the capacity for right exercise is itself one of the powers and faculties that man by nature possesses, it is not clear that man possesses "suitable powers" to achieve ultimate or permanent happiness. The capacity for right exercise may well be something other than a power or faculty-it could be, for example, part of an individual's particular "constitution" or "soul."

Moreover, the introduction of the idea of "right application" in the seventh clause, but not in the second, suggests that pursuing duty is harder than pursuing happiness because the pursuit of duty raises not only the problem that man may fail to apply his powers, but also the problem that he may apply them wrongly. The obvious and not implausible implication of this interpretation is that it is harder to figure out what you ought to do than what you would enjoy doing, even if you sincerely want to know what you ought to do. The assumption that knowing what you want to do is easier than knowing what you ought to do is fairly reasonable if one accepts the suggestion that, at least at a basic level, what most people want is wealth, security, and power. However unflattering this suggestion may seem, it is certainly true that a certain minimum level of wealth security and power are essential prerequisites to the pursuit of loftier objectives. And while it is a trite platitude that material goods will not suffice to make one happy, and that deciding the true path to happiness is a tricky matter, Story's distinction between happiness and permanent happiness ensures that platitude ample respect: even if happiness is largely material, at least at some basic level, those who seek ultimate or permanent happiness must go beyond this material happiness by pursuing virtue. But, again, this interpretation makes sense only if the second clause plays somewhat deliberately upon the tension between happiness and permanent happiness. Otherwise, since permanent happiness depends upon virtue, and virtue depends upon discernment of duty, the second clause would imply that the pursuit of duty could not be more difficult, in any fundamental sense, than the pursuit of happiness.

Yet while the pursuit of duty, and therefore the pursuit of vir- 
tue, may be difficult, Story's claim that man cannot be "permanently happy" except by the practice of virtue provides a reason to pursue virtue. His claim also provides a way to identify virtue: one may identify virtue by identifying ways to permanent happiness. There is of course a problem in that using virtue to define happiness is no good if you do not already have some understanding of virtue, and using happiness to define virtue is no good if you do not already have some understanding of happiness. So Story's definitions threaten to become circular. Story asserts in his second and seventh assumptions, however, that man has some, albeit imperfect, powers to discern and pursue both happiness and duty. These powers may include, without being limited to, man's imperfect intuition of the practical requirements of both happiness and virtue. ${ }^{80}$ As such, it is plausible that, in Story's view, all people have, or possess the powers and faculties necessary to obtain, some imperfect and contextual knowledge of both virtue and happiness. Story may thus escape the problem of circularity not by postulating some perfect, conceptual definition of either virtue or happiness, but rather by beginning from the foundation of imperfect but nonetheless helpful understandings of both virtue and happiness. The principle that the pursuit of virtue is indispensable to the pursuit of happiness provides a way to compare these imperfect intuitions, and to reason from these intuitions to more adequate understandings of both virtue and happiness.

The observations and arguments of this subsection suggest the following general interpretation of Story's thought. Story's science of natural law describes what sort of human conduct produces what sort of human happiness. While descriptive in nature, this science has obvious prescriptive implications for those who seek happiness: to be happy, one must attend to the teaching of natural law. The science of natural law is possible because man has some capacity, though not a perfect or complete capacity, to discern and pursue happiness. At a superficial but essential level, this happiness consists in satisfying human needs. The rules of natural law, therefore, must enable man to perceive power relations accurately, so as to achieve this material well-being and security.

Nonetheless, Story's assumptions recognize the existence of a permanent or ultimate happiness distinct from any summation of momentary pains and pleasures. This permanent or ultimate hap-

90 For an excellent modern discussion of the essential role played by intuition in the study of justice and philosophical thought, see Stanley Rosen, The Limits of Analysis 3-51, 149-89 (1980). 
piness is apparently analogous to what people commonly call happiness, and apparently may be experienced as happiness on Earth, but it differs from earthly happiness in that permanent happiness continues beyond death into the after-life and in that permanent happiness may for some be experienced for the first time (if at all) in the after-life. The pursuit of permanent happiness entails the pursuit of virtue, which in turn requires the discernment of duty. The discernment of duty requires the "right application" of the human faculties that study happiness and virtue, and so discerning duty is apparently more difficult than discerning the basic or superficial components of happiness. Yet although the difficulty of pursuing virtue and duty complicates the pursuit of permanent happiness, the eventual conjunction of happiness and virtue in the state of permanent happiness provides a mechanism which facilitates the pursuit of happiness: man may refine his imperfect or indistinct perceptions of happiness and virtue by a reflective comparison of those perceptions. The principles that govern this balancing are, on the one hand, that virtue is at some point indispensable to happiness, and, on the other hand, that the completely virtuous man experiences something akin to happiness. ${ }^{91}$

This interpretation of Story's science of natural law immediately reveals certain discrepancies between that science and Robert Cover's version of natural law. First, since Story's natural law appears to be partly descriptive, Cover's characterization of natural law as a way to express "the gap between law as it is and law as it ought to be" is at best an incomplete characterization of Story's science. Second, by attending simultaneously to the pursuit of happiness, virtue, and ultimate happiness, Story's natural law science is able to recognize both the requirements of duty and the practical constraints imposed by human needs and weaknesses. As a consequence, Story's natural law may be able to accommodate or justify the practical political compromises of the Constitution, and so dissolve the moral-formal dilemma central to Cover's analysis.

2. The Problem of Speculative Knowledge. The preceding section's argument produced an entirely secular interpretation of Story's science of natural law. Story's ninth sentence, however, refers explicitly to God in its first and eighth clauses, as do the fourth through eighth sentences. These references deserve attention both because one of Story's recent interpreters has argued

91 The substantive intuition of happiness, of course, must be an intuition of something more than material satisfaction, so that the reflective balancing is something more than a selfish reshaping of virtue to conform to requirements of individual interest. 
that they show that Story's vision of natural law is essentially theological, ${ }^{92}$ and because the correct explanation of Story's theological references illuminates the crucial distinction in Story's jurisprudence between practical and theoretical modes of reasoning. In this subsection I argue that Story's natural law does not depend for its meaning or import upon any claims special to Christian theology. In particular, Story's natural law is secular and rational in the sense that it does not derive from or rely upon divine revelation or divine scripture. Story's references to God are significant, however, because they suggest that the problem of justifying natural law is potentially theological in character.

The peripheral nature of Story's references to God is evident in the two references that appear in Story's ninth sentence. Story's first clause asserts, basically, that God is infinitely good. By itself, this assertion says nothing about the relation of men and women to each other or to God, and so by itself it has no implications for natural law insofar as natural law is a description of the "conduct of man." The crucial assumption is in the eighth clause, which equates virtue with obedience to the will of God. If read to suggest that human knowledge of virtue depends in whole or in part upon some independent knowledge of the will of God, this assumption would give Story's natural law an explicitly theological cast. But it is also possible to read the clause as implying that man knows the will of God only through some independent knowledge of virtue. This second reading would preserve the secularity of Story's natural law. Indeed, when taken with Story's first assumption, this second reading would equate the theological claim that man knows the will of God through knowledge of virtue with the wholly secular claim that man knows goodness or the good (or, more particularly, absolute power, knowledge, wisdom, benevolence, justice and mercy) through knowledge of virtue.

At least four considerations strongly support this reading of Story's eighth clause, which would posit that God is accessible through knowledge of virtue, rather than vice-versa. First, Story's summary in his tenth sentence of his nine assumptions mentions virtue without mentioning God. Second, Story's fourth through eighth sentences, which seem by their references to God to emphasize the theological aspects of Story's thought, in fact tend to circumscribe the importance of those aspects. The five sentences in question read as follows:

${ }^{82}$ See McClellan, Story and the Constitution at 66-69, 72-76 (cited in note 79). 
The obligatory force of the law of nature upon man is derived from its presumed coincidence with the will of his Creator. God has fashioned man according to his own good pleasure, and has fixed the laws of his being, and determined his powers and faculties. He has the supreme right to prescribe the rules, by which man shall regulate his conduct, and the means, by which he shall obtain happiness and avoid misery. He has given to man the power of discerning between good and evil, and a liberty of choice in the use of those means, which lead to happiness or misery. The whole duty of man therefore consists in two things: first, in making constant efforts to ascertain what is the will of God; and, secondly, in obedience to that will when ascertained.93

The first of these five sentences says that natural law is "presumed" to coincide with the will of the Creator. This suggests that natural law itself is known from some source other than direct knowledge of God's will, for if it were known through God's will, the coincidence of that will and natural law would be known rather than presumed. The next two sentences attribute rights and powers to God, but they do not bear upon the question of how man knows virtue. Story's seventh sentence lists the faculties that God has given man to enable him to choose among and pursue various ends. The faculties include the power to discern good and evil. Story does not say, however, that God has given man any independent power to know God's will. If Story believes man has the capacity to learn by way of divine revelation, he does not say so. The omission of any reference to revelation in Story's seventh sentence has a radical impact upon the meaning of the eighth sentence: because of the presumed coincidence of God's will and natural law, and because Story has not specified revelation as a means to knowledge of good and evil, man's task to discern and comply with God's will apparently reduces to the discernment of and compliance with the rules of natural law.

Third, when Story describes the purposes of prayer in his article, he does not include among those purposes the attainment of more perfect knowledge of virtue or natural law. ${ }^{94}$ In Story's view, prayer enables us to see into our own hearts and to reaffirm and appreciate anew our commitment to God, but not, apparently, to

${ }^{83}$ Story, Natural Law at $\mathbf{1 5 0 - 5 1}$ (cited in note 79).

24 Id. at 151. Compare this with McClellan, Story and the Constitution at 67 (cited in note 79), who erroneously claims that, according to Story, man has a duty to worship God so as to ascertain God's will. 
receive instruction by way of divine revelation. Fourth, nowhere in his article does Story make a scriptural argument to support his articulation of the particular duties arising out of natural law. This omission of any scriptural argument is particularly striking because Story devotes one-tenth of his article to a proof that marriage "is an institution, which may properly be deemed to arise from the law of nature" and that, by the law of nature, divorces should be granted only in limited circumstances. ${ }^{95}$ These topics easily give rise to scriptural arguments, but Story discusses them only by reference to the laws of nature. ${ }^{98}$

The assertion that Story's theological claims are peripheral to the meaning of his natural law science does not imply that those references are unimportant. Rather, they may be relevant to the proof of Story's fundamental assumptions. Story indicates that the assumptions he makes in his ninth sentence may be susceptible to proof: "We shall assume these propositions, not because they are not susceptible of complete proof, but because, not being intended to be discussed in this place, they nevertheless form the basis of the subsequent remarks."97 Several reasons may account for Story's view that discussion of the proofs of his assumptions may be inappropriate to his article. First, while his assumptions are a fundamental part of natural law, the proof of those assumptions

${ }^{25}$ Story, Natural Law at 152-53.

${ }^{98}$ Compare Story's ascriptural argument with the very scriptural argument of John Milton in his Doctrine and Discipline of Divorce, reprinted in Ernest Sirluck, ed., 2 Complete Prose Works of John Milton 220 (1959). Milton regarded human understanding as at least partly contingent upon revelation.

James McClellan argues that, for Story, "[n]ature's rules of human conduct. . .flowed from the same sources as God's: revelation and reason." McClellan, Story and the Constitution at 66 (cited in note 79). McClellan goes on to claim that a "conservative religious [in particular, Christian] orthodoxy" is at the heart of Story's natural law philosophy, and that Story has a "Thomistic" conception of natural law. Id.

Story's Encyclopedia article on natural law offers little support for McClellan's claim that natural law flows in part from revelation. McClellan therefore interprets the article by reference to Story's lecture on "The Value and Importance of Legal Studies." In that lecture, Story indicates that natural law "stands supported and illustrated by revelation." Story, The Importance of Legal Studies at 533-34 (cited in note 83). Yet even in that lecture, Story begins his discussion of natural law by declaring that natural law "is nothing more than those rules which reason deduces from the various relations of man. . . ." Id. at 533. Story certainly believed that the Christian religion is true, and as such coincides with natural law. Indeed, he even observes that Christianity "with many minds acquires authority from its coincidences with the natural law. . . ." Id. at 534. Story also believed that Christianity is morally edifying. As a result, he found that Christianity was useful to people-even essential to those who do not reason well or fail to reason at all. But neither of these beliefs justifies McClellan's assertion that Story's natural law philosophy is founded upon a "conservative religious orthodoxy."

${ }^{97}$ Story, Natural Law at 151 (cited in note 79). 
may belong to some subject other than the science of natural law. Second, some of the proofs may require speculative or even theological reasoning, rather than Story's practical, somewhat contextual methodology. Indeed, a "complete proof" of the claims that there is a God of infinite goodness, or that the pursuit of virtue (or obedience to God's will) is essential to the attainment of permanent happiness, would seem to entail a complete description of God, virtue, and happiness. Such a description, even if independent of theological modes of understanding, certainly raises theological issues. Moreover, such a specification, if it is indeed to be complete rather than limited, cannot rely upon practical, contextual, and therefore limited intuitions of virtue and happiness in the same way that the science of natural law may itself do.

The distinction between speculative and practical reasoning not only helps explain the significance of Story's theological references, but also accounts for Story's view of the relation of higher learning and philosophy to the practice of jurisprudence. In the introduction to his Commentaries on the Constitution Story declares that he does not have

the ambition to be the author of any new plan of interpreting the theory of the Constitution, or of enlarging or narrowing its powers by ingenious subtleties and learned doubts. . . . Upon subjects of government it has always appeared to me, that metaphysical refinements are out of place. A constitution of government is addressed to the common sense of the people; and never was designed for trials of logical skill, or visionary speculation..$^{98}$

Story apparently believes that the science of constitutional interpretation, like the science of natural law, is a practical science, one not dependent upon the sort of metaphysical speculation which would be required to prove, for example, the assumptions fundamental to natural law. ${ }^{99}$

Nonetheless, it does not follow from the inappropriateness of metaphysical refinement to the study of government that philosophical learning is unhelpful to the study of government. On the contrary, Story elsewhere recommends that the student of law

${ }^{88}$ Story, 1 Commentaries on the Constitution at vi (cited in note 21).

92 Story elsewhere asserts unequivocally that in order for the study of government to be successful, it must be practical and contextual, rather than speculative and abstract. Joseph Story, The Science of Government, in William W. Story, ed., The Miscellaneous Writings of Joseph Story 614, 616-17 (1852) ("The Science of Government"). 
"should addict himself to the study of philosophy, of rhetoric, of history, and of human nature." These studies apparently are important not for the speculative insights they provide, or for the theoretical systems they supply, but rather because they can sharpen the student's practical faculties for distinguishing good from bad. For example, the study of history forces the student to

see man, as he has been, and thereby know best what he is. He will thus be taught to distrust theory, and cling to practical good; to rely more upon experience than reasoning; more upon institutions than laws; more upon checks to vice than upon motives to virtue. $\mathrm{He}$ will become more indulgent to human errors; more scrupulous in means, as well as in ends; more wise, more candid, more forgiving, more disinterested. If the melancholy infirmities of his race shall make him trust man less, he may yet come to love man more.

Similarly, Story advises the student to study

that philosophy which is conversant with men's business and interests, with the policy and the welfare of nations; that philosophy, which dwells, not in vain imaginations, and Platonic dreams; but which stoops to life, and enlarges the boundaries of human happiness; that philosophy which sits by us in the closet, cheers us by the fireside, walks with us in the fields and highways, kneels with us at the altars, and lights up the enduring flame of patriotism. ${ }^{100}$

The string of homey metaphors that Story uses to conclude this passage should not mislead the reader into thinking that Story recommends as philosophy a sort of enlightened folk wisdom. What Story has in mind is apparently political philosophy as practiced by Aristotle, Cicero, and the writers of the Federalist rather than that practiced by Plato, Sir Thomas More, and David Hume. ${ }^{101}$ Story's skepticism pertains specifically to abstract theory and universal systems:

Nothing is so fascinating and so delusive [to young thinkers] as the simplicity of theory . . . It not only flatters that pride of opinion, which results from a supposed mastery of important truths; but it gratifies that fresh and vigourous confidence, which hopeth all things, and believeth all things ... Nothing can have a more salutary effect in repressing

${ }^{100}$ Story, The Importance of Legal Studies at 527-28 (cited in note 83).

${ }^{102}$ See Story, The Science of Government at 615-16 (cited in note 99). 
this undue pride and confidence, than the study of the science of government. The youth is there taught, how little reliance can be place upon mere abstract speculations; how often that, which is theoretically true, becomes practically mischievous; how complicated is the machinery necessary to carry on the operations of a good government; how many nice adjustments are required, to give full play and activity to the system; how slow every change must be, to be safe, as well as improving; and, above all, how often the wisest statesmen, the truest patriots, and the most profound reasoners, find defects where they had least suspected them; and their labours, begun with energy and confidence, end in disappointment and mortification. ${ }^{102}$

Thus, although "a constitution of government is addressed to the common sense of the people,"103 resolution of constitutional questions will periodically demand "great abilities, and a thorough mastery of the principles of government." In turn, a "thorough mastery of the science of government" will require "a whole life of laborious diligence."104

3. Natural Law and Positive Law. In order to apply Story's science of natural law, we must first understand the relationship between that science and positive law institutions. Story's writings suggest that positive institutions are aspirational: they are practi-

102 Id. at 636. H. Jefferson Powell, Joseph Story's Commentaries on the Constitution: A Belated Review, 94 Yale L.J. 1285, 1296 n.74 (1985), lists those passages in the Commentaries on the Constitution where Story expresses his preference for experience over theory.

${ }^{103}$ Story, 1 Commentaries on the Constitution at vi (cited in note 21).

104 Story, The Science of Government at 623, 629 (cited in note 99). In an attempt to compare the jurisprudence of Story and his contemporaries to the jurisprudence of modern constitutional scholars, Robert Bork quotes Story's assertion that constitutions are addressed to common sense without observing that common sense, as Story conceives it, may depend for refinement upon a certain kind of political philosophy and political learning. Robert Bork, Styles in Constitutional Theory, 1984 S.Ct.Hist. Soc'y Yearbook 53, 60 (1984). Bork claims that Story is different from modern scholars because Story thought that the Constitution should be interpreted rather than replaced by some "system of morality." Id. at 54. Yet because Bork fails to observe that Story recognized a distinction between kinds of philosophy, Bork makes Story appear to be naive about the difficulties of interpreting the Constitution. Story himself recognized that while the Constitution is "singularly brief and expressive," its "very brevity becomes itself a source of obscurity; and that very expressiveness, while it gives prominence to the leading objects, leaves an ample space of debatable ground, upon which the champions of all opinions may contend, with alternate victory and defeat." Story, The Science of Government at 622 . Because Bork portrays the problem of constitutional meaning as involving a choice between interpretation and philosophy, rather than as a choice between forms of philosophy, Bork leaves the interpretivists without any answer to the questions about constitutional meaning that drove today's moral philosophers away from interpretation in the first place. 
cal means chosen to pursue, with the hope of eventually achieving, natural law ends that circumstances may make unattainable at present.

Story gives us some sense of his view of the aspirational character of institutions in his introductory comments in Prigg. After summarizing the facts of the case and remarking upon the importance of the question presented, Story prefaces his analysis of the issues with a paragraph on the nature of constitutional interpretation, which says in part:

[I]t may be well-in order to clear the case of difficulty-to say, that in the exposition of this part of the Constitution, we shall limit ourselves to those considerations which appropriately and exclusively belong to it, without laying down any rules of interpretation of a more general nature. It will, indeed, probably, be found, when we look to the character of the Constitution itself, ... as well as the known historical fact that many of its provisions were matters of compromise of opposing interests and opinions, that no uniform rule of interpretation can be applied to it, which may not allow, even if it does not positively demand, many modifications in its actual application to particular clauses. And, perhaps, the safest rule of interpretation after all will be found to be to look to the nature and objects of the particular powers, duties, and rights, with all the lights and aids of contemporary history; and to give to the words of each just such operation and force, consistent with their legitimate meaning, as may fairly secure and attain the ends proposed. ${ }^{105}$

It is tempting to dismiss this paragraph as indeterminate and unilluminating dicta, or, if one is more cynical, as an unwitting concession to the inefficacy of legal reasoning. While far from obvious, however, one possible interpretation of Story's paragraph makes the paragraph consistent with much of Story's jurisprudential thought and prefigures Story's disposition of Prigg itself. Story's opening paragraph suggests that, in the absence of political compromise, constitutional interpretation might rest upon a unitary interpretive principle: one would need only to ascertain what interpretation would result in a state of affairs that was good and just, since there would be no good reason for constitution-makers to have imposed or have aimed at any other state of affairs. But the necessity of compromise compels constitution-makers to attend

${ }^{105}$ Prigg v. Pennsylvania, 41 U.S. 539, 610-11 (1842). 
to matters of special interest and convenience as well as to what is just and good. So it is not good enough when interpreting the Constitution to ask simply what is right and good, or to apply principles for determining what is right and good. Particular clauses will reflect particular compromises, and it is important to know what those compromises were.

Story also investigates the implications of natural law for particular aspects of positive law in his article on natural law. Story does not specifically consider either the problem of slavery or the American response to slavery. However, Story's treatment of the natural law foundations of such institutions as marriage, civil society, and private property does suggest a particular relationship between positive and natural law. This relationship provides a basis for analyzing the natural law foundations for the American Constitution's approach to slavery. In general, Story demonstrates the natural law foundations for positive law institutions by showing that those institutions restrain various human tendencies that destroy human happiness (like greed, ambition, weakness, and fear) or develop various human capacities that are conducive to happiness (like compassion, productivity, friendship, magnanimity, and justice).

Story's discussion of marriage is a good example of this method. ${ }^{106}$ According to Story, marriage is an institution in accord with natural law because it promotes "the private comfort of both parties," it tends to the procreation and education of healthy citizens, it diminishes fights that might arise out of jealousy and rivalry, it inculcates domestic virtues, and it furnishes additional motives for "honest industry and economy in private life."107 For Story, marriage is a positive institution that accords with natural law both because it shapes human relations in a way conducive to happiness, and because it protects against human tendencies destructive to happiness.

In similar fashion, Story's brief account of the purposes of civil society identifies man's dependence on the cooperation of others for protection against external aggression as a fundamental reason for the formation of civil society. Story observes:

${ }^{108}$ Indeed, it is possible that Story includes his surprisingly long discussion of marriage largely for its illustrative value. Story devotes approximately the same amount of space to the topic of marriage as he does to the topics of civil society and the nature of property rights. As the topic of marriage is less comprehensive than the topic of civil society, it is more susceptible of complete treatment.

${ }^{102}$ Story, Natural Law at 152 (cited in note 79). 
It is obvious, that no single individual can protect himself to the same extent, or by the same means, as an organized society or government can protect him. . . . Men enter, then, into civil societies for the protection of their persons, and personal rights and property.

Civil society accords with natural law largely because it allows for the creation of a central authority capable of adjudicating and redressing harms that individuals inflict upon one another. Of course, to say that protection (from neighbors, foreigners, or the extremes of nature) is a primary purpose of civil society is not to exclude the possibility that the institution may also have as its purpose the creation of new opportunities, such as, for example, the opportunity to participate in political debate. Civil society recognizes both the need for cooperation (man's dependence) and the capacity for happiness: "Civil government, then, may be properly said to consist in the exercise of such delegated powers, as are proper or necessary for the safety, protection and happiness of the whole community."108

Story places the institution of private property on a similar footing. According to Story,

in a state of nature, each man actually appropriates to himself whatever he desires, and can get; and he then holds it by the title of the strongest; and no other person respects his title any longer than it can be so maintained, though no one can show a better title to it.

In short, in the state of nature, physical possession is the sole source of property rights, and physical strength is their sole guarantor. This extremely limited (by comparison with, for example, the Lockean argument that one gains property in objects by mixing one's labor with those objects) property right is deduced from the human need for food and other supplies, and from the human capacity to procure and use food and supplies. Eventually, according to Story, people learn that allowing stores of property to accumulate benefits all:

Thus the first rudiments of exclusive property begin in the fact of actual possession and power, and the title gains strength and permanence from a sense of the beneficial results to the interests of all the neighborhood, and, ultimately, to the whole society, with which each family and tribe are con- 
nected. The advantages of the admission of such an exclusive right are soon felt by all reflecting minds, and gradually prepare the way for a more solemn recognition of it. ${ }^{109}$

Exclusive property rights, then, rest not only on the recognition that human happiness depends upon the acquisition and use of property, but also on the observation that the development of exclusive, lasting rights increases productivity and industry, and so alleviates scarcity and want.

While Story's analysis thus provides a natural law foundation for property rights, inasmuch as those rights foster productivity, facilitate the satisfaction of needs, and diminish fighting, that analysis neither produces specific rules governing property rights nor provides individuals with the kind of strong, natural right claims to their possessions assumed by such political theorists as, for example, Robert Nozick. ${ }^{110}$ Indeed, Story states expressly:

Whatever right a man may have to property, it does not follow, that he has a right to transfer that right to another, or to transmit it, at his decease, to his children or heirs. The nature and extent of his ownership; the modes in which he may dispose of it; the course of descent, and distribution of it upon his death; and the remedies for the redress of any violation of it, are, in great measure, if not altogether, the result of the positive institutions of society. ${ }^{111}$

In summary, then, Story believes that natural law identifies both those human purposes which positive institutions should further and those human tendencies which positive institutions must, if they are to achieve their ends, recognize. At least three aspects of this relationship between natural law and positive institutions are worth noting. First, the content of natural law is more prescriptive than proscriptive: it specifies the ends to be pursued and the means for their attainment, rather than merely specifying rules or prohibitions (including, for example, "do not enslave your fellow man or woman") to be obeyed. Second, positive law faces the problem of selecting among means, and, in particular, the problem that as a practical matter, not all of the ends identified by natural law may be achieved immediately or within the foreseeable future. Positive law institutions may therefore legitimately have an aspira-

100 Id. at 155.

110 Robert Nozick, Anarchy, State and Utopia (1974). Nozick assumes the existence of sufficient natural property rights to justify his rules of just transfer.

${ }^{111}$ Id. at 155-56. 
tional character, in the sense that they may aim at ends which they, by their very structure, recognize have not yet been achieved and may not in the near future be achieved. ${ }^{112}$ Third, because positive law institutions are the product of a selection among means, the choice of appropriate positive law institutions will depend upon contextual considerations. Different societies will face different practical problems, and so may require different institutions to achieve the same ends. ${ }^{113}$

In light of these three aspects of Story's view of the relationship between natural law and positive law, it appears that natural law, contrary to Cover's view, expresses not so much the gap between what the law is and what the law ought to be, but rather the gap between what the polity is and what the polity ought to be. In particular, since the natural law does not consist of a set of interdictions, the natural law does not present an alternative to the positive law. Rather, the natural law consists in part of a set of ends to be practically achieved. Positive law institutions must therefore recognize, confront, and overcome the practical social, economic, and intellectual barriers to the achievement of natural ends.

\section{Conclusion: The Natural Law Foundations of the Constitutional Treatment of Slavery}

If Story viewed the American constitutional order as being aspirational, what does that imply for his understanding of the fugitive slave clause? The positive law institutions that addressed the American problem of slavery aimed to achieve at least two natural law ends. The first of these ends is the elimination of slavery. It should perhaps be enough to say that this end is self-evident, that is, immediately discernible from our practical intuitions of virtue and happiness. ${ }^{114}$ Story himself did not devote much energy to explaining why natural law requires the elimination of slavery. However, if argument is necessary, Story's brief writings on the topic

112 For an excellent modern formulation of aspirational constitutionalism, see Sotirios A. Barber, On What the Constitution Means (1984).

113 This account of the just role played by positive institutions accords with the theory of government expressed by the Declaration of Independence and endorsed by Story. See Story, 1 Commentaries on the Constitution at $\$ 330$ (cited in note 21) (emphasis in the original).

114 To say that the end is self-evident does not imply that it is necessarily uncontroversial. People may, for various reasons, not understand an idea that is self-evident, or may dispute what they know to be true. See Finnis, Natural Law and Natural Rights at 65 (cited in note 2). 
suggest three lines of reasoning. First, Story argues that slavery is manifestly inconsistent with the American constitutional commitment to the equality of all men. ${ }^{115}$ While this inconsistency is persuasive, this argument shows only that slavery is inconsistent with positive constitutional principles, not those of natural law. ${ }^{116}$ Second, Story argues that slavery is wrong because it makes the enslaved accountable for acts that they do not direct, and so contradicts the axiom of the natural law that all men are ultimately accountable for their actions. ${ }^{117}$ Third, great misery necessarily attends slavery. ${ }^{\mathbf{1 1 8}}$

The second of the two ends for the Union is its preservation. The Union is of course a positive law institution, so its preservation can be necessary as a matter of natural law only if the Union is essential to the attainment of deeper natural law ends. The Union in fact does serve some very important natural law ends: like other forms of civil society, the Union provides for an exclusive system of property rights, the legal resolution of disputes, and protection against oppression by foreigners. As such the Union attends to human weakness by facilitating the pursuit of material wealth and security. The Union also guarantees some freedom to pursue diverse religious and philosophical speculations. ${ }^{119}$ While it is clear that the Union promotes these ends, it is less obvious that the Union is essential to their pursuit or achievement. It is possible that an association of smaller governments, or smaller governments acting independently, could achieve these ends equally well or better than the Union. Nonetheless, the shortcomings of the Confederation that preceded the Constitution are, at the very least, evidence that substantial risks of economic and military weakness, and perhaps even bad constitutions (for example, a Southern constitution that accepts the permanence of slavery as morally unobjectionable), would accompany dissolution of the Union. Moreover, conceiving an alternative to the Union would require a rather comprehensive exercise of speculative reason, which according to Story is unreliable. ${ }^{120}$ In light of these considerations, the aim of preserv-

115 Story, Piracy and the Slave Trade at 140 (cited in note 21).

${ }^{116}$ It may be, however, that a commitment to equality is in some sense essential to securing the purposes of civil society.

${ }_{117}$ Story, Piracy and the Slave Trade at 141.

${ }^{118}$ Id. at 141. See also La Jeune Eugenie, 26 F.Cases at 845-46.

${ }^{119}$ See U.S. Const. amend. I.

${ }^{120}$ Comprehensive reasoning about constitutional principles may however prove inevitable, although difficult, even within the political structure of the existing constitution. For an important recent study of the way in which different understandings of constitutional 
ing the Union is at the very least founded in natural law, if not essential as a matter of natural law.

Because there is no apparent way to achieve immediately both the preservation of the Union and the elimination of slavery given the interests of the slaveholding Southern states, the Constitutional treatment of the slavery problem must be aspirational in the sense described in the preceding section: it must aim at both a more perfect union and the elimination of slavery, while recognizing both the Union's present diversity and slavery's present persistence. Moreover, the aspirations of the Constitution may be somewhat indistinct, in the sense that the methods and timetable for achievement of the two ends aimed at may be unforeseeable. This unforseeability arises out of the limitations of practical reason: practical intuitions of virtue and happiness may suffice to indicate that the eventual elimination of slavery is a necessary end and that certain present accommodations of slavery are necessary, without indicating how or when slavery will be eliminated. This more general problem of the future course of events is one of visionary speculation, although the problem of choosing a correct action at any given point in that course will be a practical one.

With these general considerations in mind, we may spell out the answers to the four particular questions with which I began Section III. First, what sense can be given to the idea of a peculiarly positive right? Since Story assumes that there are some prelegal rights (including, for example, the right to what one possesses and has the power to keep), peculiarly positive rights might be those rights recognized by positive law which go beyond rights that exist in pre-legal or pre-political society. In this view, the category of peculiarly positive rights is quite broad: indeed, it would include, for example, nearly all of the legal rules governing property rights. There is, however, a second notion of peculiarly positive rights which seems more appealing and fits better with Story's use of the idea in Prigg: certain laws may be peculiarly positive in the sense that the rights they establish are not founded in natural law at all. On this reading of the "peculiarly positive" idea, most of the laws governing property rights are not peculiarly positive since exclusive property rights are founded in natural law, even if the particular rules enforcing property rights neither are mandated by natural law nor were a part of pre-legal or pre-political society. The state laws authorizing slavery, on the other hand, might well

principles have shaped American political life at both the architectonic and the particular levels, see Jeffrey K. Tulis, The Rhetorical Presidency (1987). 
be peculiarly positive even on this second, more narrow definition, particularly if they do not aim at the eventual elimination of slavery. The existence of aspirational institutions, which acknowledge and accept conditions which they aim to alter, suggests a further refinement of the second definition of peculiarly positive rights: those rights which aspirational institutions create, but aim eventually to eliminate, are peculiarly positive because, while they are necessary for the positive law pursuit of certain natural law ends, they are inconsistent with the attainment of other natural law ends.

The refined second definition explains the idea of peculiarly positive rights in a manner that buttresses Story's analysis in Prigg. Story found it important that the right guaranteed by the fugitive slave clause was "new and positive" in the sense that there was no pre-constitutional moral or political duty to respect the claim of slaveholders wishing to recapture fugitives. ${ }^{121} \mathrm{~A}$ right that is peculiarly positive, one that is inconsistent with the attainment of some end specified by natural law as essential to human happiness, meets this condition: there can be no duty to guarantee the right, since the right itself by definition is inessential to human happiness. The right, if it exists in a way that accords with natural law, can exist only as a positive regulation designed to address some practical and, one hopes, temporary obstacle to the attainment of happiness. Story's science of natural law thus adequately explains his distinction between positive and natural rights in Prigg. ${ }^{122}$

Second, what is the difference between a municipal regulation, which aims to further local interest and convenience, and other laws, which may aim to further the public good? The contrast between interest and convenience on the one hand and the public good on the other recalls the distinction, discussed earlier, between happiness and ultimate, permanent, or complete happiness. The essence of that distinction was that happiness might be understood at times to encompass only material satisfaction, while ultimate happiness depends upon the pursuit of virtue. One possible distinction between the public good and local interest and convenience is that the latter might aim only at happiness, while the

${ }^{121}$ See Prigg, 41 U.S. at 622-23.

122 The first definition of peculiarly positive rights developed above of course inadequately explains Story's distinction, since, while rules governing the disposition of private property are peculiarly positive under the first definition, legislatures do have a pre-constitutional political duty to enact some such rules. 
former aims at complete or ultimate happiness. In the context of the American slavery problem, regulation of slavery would aim at the public good only if it aimed at the eventual elimination of slavery.

Again, this analysis explains Story's position in Prigg. As shown earlier, the distinction between municipal regulations and other laws, and the related distinction between interest and convenience on the one hand and the public good on the other, was important to Story's argument. On the interpretation developed in the preceding paragraph, the federal constitutional law of fugitive slaves might aim at something more than interest and convenience if it sought the eventual, national elimination of slavery. Local law in the Northern states, by contrast, might have destroyed or outlawed slave-related institutions (including the returning of fugitive slaves) in the Northern states, but it might well have had the long term effect of dissolving the Union. This in turn could have extended the life of slavery in the South. Local Northern law would therefore tend to the interest and convenience of the Northern states, but that law would not effect a national solution to the slavery problem.

Similarly, since the South had an economic interest in the preservation of slavery, it was likely to enact laws that recognized a permanent, or at least morally unobjectionable, place for slavery. As a consequence, only national laws were likely to promote the national policy of eliminating slavery, and thus only national regulation of slavery was likely to rise above the status of mere municipal regulation to the status of law aimed at the public good. Thus, Story's science of natural law explains the distinction between local interest and public good, and between municipal regulations and other laws, in a way that makes it plausible to suggest that one purpose for the fugitive slave clause, a purpose which distinguishes the clause and laws enacted under it from local regulations, is to bring the fugitive slave problem within the ambit of national political discourse so as to facilitate a national solution to the slavery problem.

Third, does Story's jurisprudence overlook either (as Dworkin suggests) the possibility of jurisprudence more closely tied to moral philosophy or (as Newmyer suggests) the need for a jurisprudence capable of critically judging the substantive moral and political premises of American constitutionalism? The answer to the two halves of this question follows fairly immediately from the interpretation of Story's article advanced above. Dworkin errs by characterizing Story and other nineteenth century judges as choosing 
between an unimaginative and deferential positivism on the one hand and an institutionally ungrounded natural law theory on the other. Indeed, Story would almost certainly have endorsed Dworkin's jurisprudential claim that the "general structure of the American Constitution presupposed a conception of individual freedom antagonistic to slavery [and] a conception of procedural justice that condemned the procedures established by the Fugitive Slave Act," and that these principles were "more central to the law than were the particular and transitory policies of the slavery compromise." 123 Moreover, as shown earlier, Story believed that the resolution of difficult constitutional questions required the deliberate and thoughtful study of philosophy and history.

However, Story and Dworkin part company in two important and related respects. First, Story regards the central constitutional principles of freedom and procedural justice as ends to be achieved, while Dworkin appears to regard these principles as immediately binding legal rules to be applied by judges. Dworkin's position presupposes either a belief that the practical realization of these principles is an immediate consequence of their judicial articulation and application, or a belief that judicial articulation and application of these principles is more important than their practical realization. Story by contrast views the policies embodied in the Constitution not as alternatives to fundamental constitutional principles (as Dworkin suggests) but rather as the practical consequence of the commitment to pursue those principles.

Second, although Story and Dworkin believe that recourse to moral and political considerations is essential to constitutional interpretation, Dworkin's view of that recourse directs judges to engage in precisely the sort of visionary speculation that Story thought was unsuited to judicial decision-making. Dworkin acclaims John Rawls' $A$ Theory of Justice, an entirely theoretical study which begins from an imaginary, ill-defined "original position," as "better philosophy" than what existed in the pre-Rawlsian era. ${ }^{124}$ Yet while Story rejects this particular form of reasoning for purposes of constitutional interpretation, that rejection certainly does not stem from ignorance of the possibility of employing methods similar to Dworkin's; on the contrary, Story takes care to

123 Dworkin, Law of the Slave-catchers at 1437 (cited in note 50 above). Dworkin also claims that the Constitution embraced a conception of federalism inconsistent with federal control over recapture of fugitive slaves. Id. It seems unlikely that Story would have joined Dworkin on that point.

${ }^{224}$ See Ronald Dworkin, Taking Rights Seriously 149 (1977). 
distinguish philosophy grounded in experience from philosophy that is speculative, theoretical and visionary. Dworkin, by contrast, does not make this distinction. ${ }^{125}$

The two disagreements between Story and Dworkin are closely related. For Dworkin, judicial reasoning in hard cases depends largely upon identifying the principles of justice. Judges must therefore have recourse to abstract and theoretical philosophy that attempts to develop and state a general theory of justice or the good. For Story, judicial reasoning in hard cases largely involves identifying the proper means to pursue the public good in a particular context. Judges must therefore have recourse to a practical philosophy that explains the implications of particular details and circumstances for the pursuit of justice.

This formulation of the disagreement between Story and Dworkin reveals that, at the very least, my exposition of natural law defeats the particular arguments Dworkin directs at Story. Dworkin reasons that Story's failure to decide the slavery cases in a politically acceptable manner resulted from a jurisprudential inability to resort to moral and political considerations when interpreting and applying positive law. As we have seen, Story's jurisprudence does provide an argument that Prigg was rightly decided and does make recourse to political and moral considerations when interpreting the Constitution. It remains possible that Dworkin's jurisprudence may be preferable to Story's for reasons other than those stated by Dworkin, but resolution of that issue turns upon arguments outside the scope of this comment.

It is more difficult to meet Newmyer's criticisms. Certainly Story lacked the sort of "jurisprudential self-consciousness" that has led many more recent legal scholars to "think about thinking." Certainly, too, Story accepted certain "intellectual and historical premises," and regarded those premises as the foundation for a community "united in purposes, values, and beliefs." Nonetheless, it is possible to make at least three points in response to Newmyer. First, Newmyer repeats Dworkin's argument that Story's jurisprudence could not handle the slavery cases. ${ }^{128}$ As shown above, this argument is wrong. Story's "intellectual and historical premises"

${ }^{125}$ Indeed, Dworkin seems to consider his own work uniquely practical by comparison with the bulk of political philosophy. "The great classics of political philosophy are utopian. . . . Ordinary politics adds to . . . familiar ideals a further one that has no distinct place in utopian axiomatic theory." Dworkin then goes on to unveil the value he calls "integrity." Dworkin, Law's Empire at 164-65 (cited in note 50).

${ }^{22 B}$ See Newmyer, Justice Joseph Story at 390 (cited in note 21). 
with respect to slavery might have been flawed, but Newmyer does not tell us what those flaws were. ${ }^{127}$ Second, while, as Newmyer asserts, growing political complexity or, more likely, the growing opportunity to reflect upon political complexity, has generated a healthy skepticism in this century about "easy answers" to legal questions, the possibility of relativism does not itself justify relativism. To endorse relativism out of a skepticism about easy answers is to make relativism itself an easy answer. Recognizing that answers to legal questions require difficult and thoughtful justification does not preclude the possibility that such justification exists. Moreover, even today's problems demand practical solutions: while we may have more luxury than did Story to indulge in skepticism and relativism, we ourselves, like Story, are in need of jurisprudence capable of allowing us to "build well."128

Third, it is not clear that Story erred in supposing that the United States was, or could become, a community united to a significant degree by shared practices, values and beliefs. Charles Black has argued that the Civil War amounted to a vindication of John Marshall's belief, shared by Story, that the United States was indeed one nation. ${ }^{129}$ Present differences among Americans about justice may indicate the difficulty of answering the speculative and theoretical questions about the nature of justice, rather than signifying the absence of any single correct answer to the practical question of what justice requires in a particular context.

In brief, then, both Dworkin and Newmyer claim that Story's jurisprudence was incapable of deciding the slavery cases appropriately, and stress the importance of contemporary disagreement about principles of justice. Story's science of natural law furnishes an answer to the first contention by providing a firm foundation for the claim that Story's decision in Prigg was faithful to a Constitution that aspired to the creation of a unified republic free from slavery. Story's thought also furnishes an answer to the second half of the argument through Story's distinction between speculative and practical philosophy. Current disagreements about the meaning of justice may be largely the consequence of the inherent difficulty and unreliability of speculative, theoretical inquiries into po-

${ }^{127}$ See Newmyer's critical discussion of Prigg. Id. at 369-78.

128 Id. at 390.

${ }^{129}$ Charles L. Black, The Unfinished Business of the Warren Court, 46 Wash.L.Rev. 3, 3-5 (1970). See also Martin Diamond, Ethics and Politics: The American Way, in Robert H. Horwitz, ed., The Moral Foundations of the American Republic 39 (1977) (arguing that there is a particularly American way of life). 
litical matters. Though they are still difficult, practical inquiries into particular political problems are less difficult than abstract speculation. Moreover, since practical inquiries depend upon recourse to contextual intuitions, rather than upon application of or deduction from a general theory of justice, the absence of any agreed theory of justice does not preclude the rational resolution of particular constitutional questions. Story's thought on natural law thus answers the claims of Dworkin and Newmyer that Story does not come to terms with the dependence of judicial reasoning upon moral and political considerations.

Finally, does an ethical, as well as an institutional, justification exist for Story's opinion in Prigg? In light of what has already been said, this difficult question may now be answered fairly quickly. Cover errs by characterizing natural law as an expression of the gap between what the law is and what the law ought to be. In Story's view, natural law expresses the gap between what the polity is and what the polity ought to be or become. The difference between these two characterizations of natural law is significant, for the latter admits the possibility that positive law may be aspirational: it may recognize institutions which it will tolerate for the time being with the aim of eventually eliminating them. Put this way, Story's version of natural law more readily accommodates practical barriers to the achievement of natural law ends than does Cover's. According to the interpretation of Story's opinion in Prigg advanced here, the fugitive slave clause is precisely such an accommodation: it aims simultaneously at the eventual elimination of slavery and the creation of a more perfectly unitary nation, while recognizing the present existence of slavery and sectional conflict. Because Story's natural law permits-indeed, encourages-the development of aspirational institutions, the moral-formal conflict described by Cover never arises for Story.

Story's natural law science therefore provides a wholly satisfactory answer to the modern ethical criticisms of Story's opinion in Prigg. Whether that science likewise answers other modern questions not articulated in this comment is left to the speculation of the reader. 